\title{
Diatom-inferred ecological responses of an oceanic lake system to volcanism and anthropogenic perturbations since $1290 \mathrm{CE}$
}

David Vázquez-Loureiro ${ }^{\mathrm{a}}$, Vítor Gonçalves ${ }^{\mathrm{b}}$, Alberto Sáez ${ }^{\mathrm{c}}$, Armand Hernández $^{\mathrm{a}, \mathrm{d}}$, Pedro M. Raposeiro ${ }^{b}$, Santiago Giralt ${ }^{d}$, María J. Rubio-Inglés ${ }^{d}$, Valentí Rull ${ }^{d}$, Roberto Bao ${ }^{a^{*}}$

\footnotetext{
${ }^{a}$ Centro de Investigacións Científicas Avanzadas (CICA), Facultade de Ciencias, Universidade da Coruña, A Coruña, Spain

${ }^{\mathrm{b}}$ Centro de Investigação em Biodiversidade e Recursos Genéticos, CIBIO, InBIO Laboratório Associado, Pólo dos Açores \& Faculdade de Ciências e Tecnologia da Universidade dos Açores, Ponta Delgada, Açores, Portugal

${ }^{\mathrm{C}}$ Department of Earth and Ocean Dynamics, Universitat de Barcelona, Barcelona, Spain

${ }^{d}$ Institute of Earth Sciences Jaume Almera (ICTJA-CSIC), Barcelona, Spain
}

How to cite

Vázquez-Loureiro, D., Gonçalves, V., Sáez, A., Hernández, A., Raposeiro, P.M., Giralt, S., Rubio-Inglés, M.J., Rull, V., Bao, R., 2019. Diatom-inferred ecological responses of an oceanic lake system to volcanism and anthropogenic perturbations since $1290 \mathrm{CE}$. Palaeogeogr. Palaeoclimatol. Palaeoecol. 534, 109285. doi:10.1016/.jpalaeo.2019.109285

“roberto.bao@udc.es 


\section{Abstract}

The impacts of natural- and human-induced processes on lake ecosystems in remote oceanic islands remain to be fully elucidated. These lakes are excellent candidates to analyze the importance of anthropogenic vs. natural forces driving lacustrine long-term ecological evolution from previous pristine pre-colonized conditions. Disentangling the effects of both is particularly relevant in highly active volcanic areas, where catastrophic eruptions can act as an atypical natural driver altering the lake's long-term ecological trajectories. In this paper we study past ecological changes occurring in Lake Azul (São Miguel island), a crater lake from the remote Azorean archipelago, to address which were the main causes of its long-term trophic history. We analyzed diatom assemblages, sedimentology, and bulk organic matter of sediments deposited since ca. $1290 \mathrm{CE}$, when a huge local eruption occurred. This episode drove the evolution of Lake Azul through six distinct phases, commencing with a restart of ecological succession after tephra deposition disrupted biogeochemical cycling. The alteration was so profound that the lake underwent a state of oligotrophic conditions for approx. 650 yr. Nutrients were sourced by fishinduced internal recycling and the overflow of the near Lake Verde during this period, rather than by allochthonous nutrient inputs modulated by climate variability and/or vegetation cover changes in the watershed after the official Portuguese colonization. It was only after recent artificial fertilization when the system overcame the volcanic-induced long-term resilience. This over-fertilization and a reduction in water turnover exacerbated the recent symptoms of eutrophication after 1990 CE. Contrary to other studies, Lake Azul constitutes an uncommon case of long-term resilience to trophic change induced by a cataclysmic volcanic eruption. It brings new insights into the fate of lake ecosystems which might be affected by similar events in the future. 


\section{Keywords}

Eutrophication; oligotrophication; lake ontogeny; invasive species; volcanic eruptions; regime shifts 


\section{Introduction}

Oceanic islands have been particularly sensitive to the effects of anthropogenic impacts, despite being subjected to relatively recent human colonization extending back to only the last centuries. Human impacts usually have striking effects on their ecosystems because of their isolated location and usually very small sizes. Forest clearance (CañellasBoltá et al., 2013), exotic species introduction (Sax and Gaines, 2008) or local species extinctions (Wood et al., 2017) are among the most prominent impacts exerted by human colonization on oceanic islands. But whereas the effects of human colonization on terrestrial landscapes are well known, the impacts exerted on aquatic ecosystems still remain to be more fully understood.

The Azores archipelago (Macaronesian biogeographical region) lies in the middle of the North Atlantic Ocean and it was officially colonized by the Portuguese in 1432 CE. Since precolonization times to present, notable landscape changes occurred related to, first, pure extractive activities, and, later, transformation by agricultural and livestock management (Dias, 1996). Palynological paleoenvironmental reconstructions have shown that anthropogenic impact in the Azores largely surpassed natural processes, such as volcanism or climate change, as main drivers of landscape changes (Connor et al., 2012; Rull et al., 2017). Less is known however on the human-driven impacts on the rich mosaic of lake ecosystems of the archipelago. This knowledge is of particular importance since studies have shown that insularity makes lakes from the Macaronesian region to be markedly different to their continental counterparts from an ecological perspective (Hughes and Malmqvist, 2005).

In the short-term, water quality deterioration due to cultural eutrophication has been reported in the Azores lakes since the 1980's related to agricultural and farming activities (Gonçalves, 2008; Cruz et al., 2015). Yet, the lack of detailed and regular limnological data 
before water quality monitoring surveys started in 1992-1993 (Cruz et al., 2015) hinder any evaluation of the response of the Azorean lakes to the long-term cultural eutrophication and its potential causes, not exclusively related to recent artificial fertilization. It is known that changes in the food webs are another mechanism which can profoundly alter the trophic trajectory of any lake ecosystem (Smith, 2003). It is particularly relevant how the abundance and structure of fish communities modify the interactions between zooplankton and phytoplankton. Fishes can promote algal biomass both by predation on zooplankton (top-down control) and by nutrient recycling when their activity at the lake bottom stir up the sediments (bottom-up control) (Scheffer and van Nes, 2007). This seems to have been the case of the formerly fishless Azorean lakes Furnas and Fogo (São Miguel island), which were not only very sensitive to artificial nutrient loading, but also to trophic web controls after the introduction of detritivorous fishes which promoted eutrophication (Skov et al., 2010; Buchaca et al., 2011). As it has been addressed elsewhere, cultural eutrophication is therefore the result of cumulative actions, distant in time and space, which make it difficult to disentangle past and present causes from the legacy of past anthropogenic activities (Thornton et al., 2013; Le Moal et al., 2019).

Besides human direct actions on freshwater ecosystems, it is also necessary to assess the relative importance of natural processes which can also induce increases in productivity, as climate-related or volcanic factors. Volcanism in particular could be a potential significant source of nutrient enrichment in the highly active volcanic Azorean context. Ash deposition after volcanic eruptions can prompt significant phytoplankton growth by nutrient enrichment and attenuation of excessive light intensities (Modenutti et al., 2013), but it can also have the opposite effect interfering with nutrient balances which in turn can strongly reduce productivity (e. g., Barker et al., 2000). Although the amount of volcanic-derived nutrients is at present negligible in terms of changes in trophic state of the Azorean lakes (Cruz et al., 2006), this might not have been the case in the past, when 
volcanic activity was much more common (Queiroz et al., 2008). Yet, the very short time spans covered by studies in lakes Fogo (approx. 150 yr; Skov et al., 2010) and Furnas (approx. $50 \mathrm{yr}$; Buchaca et al., 2011) does not allow the determination of the precise role played by tephra deposition in the trophic status of lakes in the archipelago.

Finally, any eutrophication effect on a collection of different lake systems, natural- or human-induced, must take into account that each lake has own characteristics which makes it unique regarding resistance, resilience and trajectory (Thornton et al., 2013; Le Moal et al., 2019). For instance, for assessing the effects of exotic fish introductions it is necessary to consider a large array of trophic conditions, since understanding the coupling between zooplankton and phytoplankton is dependent on nutrient levels (Elser and Goldman, 1991). Such array of trophic conditions can be found in lakes of the Azores with studied paleorecords. The mentioned lakes Furnas and Fogo constitute examples of systems with distinct trophic status, eutrophic-hypereutrophic and mesotrophic respectively (Skov et al., 2010; Buchaca et al., 2011). Yet, the paleoenvironmental reconstructions from these lakes do not show periods of extended oligotrophy. By contrast, historical accounts (Barrois, 1896; Bohlin, 1901) and fossil chironomid data (Raposeiro et al., 2017) point to past persistent oligotrophy in Lake Azul (São Miguel island), the largest lake of the Azorean archipelago. This lake constitutes an excellent candidate to understand changes in trophic status due to anthropogenic and natural forcings acting in an insular lotic system from a former oligotrophic condition, particularly as the chironomids (Raposeiro et al., 2017) and pollen (Rull et al., 2017) have been analyzed from the same Lake Azul core.

In this study we reconstruct the environmental history of Lake Azul since early human colonization, focussing on its response to both natural (volcanism and climate-related drivers) and anthropogenically-induced perturbations (i. e., changes in land use, exotic species introduction, and over-fertilization). We aim to understand the resilience of Lake 
Azul to different long-term causes of eutrophication, contrasting it with analogous lake systems in the Azorean archipelago and elsewhere which had a different trophic status in the past or present. Such a study on the long-term combined effects of different types of nutrient loading, biological invasions and natural forcings, a key issue in contemporary ecology (Ellis et al., 2011), has barely been addressed in insular lake systems and/or those affected by catastrophic volcanism. Understanding the long-term changes in the trophic condition of Lake Azul provide a much better insight into the process of recent eutrophication affecting this lake.

\section{Geological, climate and limnological settings of Lake Azul}

Lake Azul is located in Sete Cidades caldera $\left(37^{\circ} 51^{\prime} \mathrm{N}-25^{\circ} 46^{\prime} \mathrm{W}\right)$, which occupies the westernmost part of São Miguel Island (eastern sector of Azores archipelago) (Fig. 1). Three major eruptive phases, at approximately 36, 29 and $16 \mathrm{kyr}$ BP, conditioned the caldera formation (Queiroz et al., 2008). The subsequent explosive Holocene eruptions formed secondary volcanoes inside the caldera, generating ash and lapilli volcanoclastic deposits (Queiroz et al., 2008). At present, the bottom of some of these secondary volcano craters are occupied by perched lakes. Tephra deposits from Holocene eruptions of secondary volcanoes accumulated both inside and in source areas of the lakes. The most significant and recent eruptive episode which accumulated tephra in lakes of Sete Cidades was the P17 eruption, which occurred in the Caldeira Seca volcano in the last millennium (Queiroz et al., 2008, Shotton and Williams, 1971; Fig. 1) and which consisted in three different phases of lapilli deposition (phases L1, L2 and L3 according to Cole et al., 2008).

Lake Azul is located approximately 260 m above sea level (Pereira et al., 2014) and has an irregular bottom topography, resulting from faults affecting the substrate (Queiroz, 1997). It can be divided into three main physiographic zones, from south to north, in an 
increasing depth gradient (Figs. 1D and 2): (1) a shallow platform or ramp (0 to $\sim 12 \mathrm{~m}$ depth), (2) a rise ( 12 to $\sim 24 \mathrm{~m}$ depth) related to an extensional fault slope, and (3) a deep offshore plain ( 24 to $27 \mathrm{~m}$ depth). The deep plain receives water and sediments from ephemeral streams located at the north of the inner caldera wall and from a main river forming a delta system at the east, close to the locality of Cerrado das Freiras (Fig. 1). Lake Azul is a part of a more complex lacustrine system inside the Sete Cidades caldera which includes a second large waterbody located at its southern side, Lake Verde, to which it is connected hydrologically by an inundated isthmus. Yet, historical accounts show that the two lakes were separate water bodies in the past, as deduced by descriptions of the $16^{\text {th }}$ century (Frutuoso, 1977) or by the cartographic representation which still shows the two lakes in isolation in 1844 CE (Vidal, 1850). Hydrologic connection occurred in 1877 CE, according to local accounts (Andrade, 2003) and a preserved pictorial engraving (Reclus, 1830-1905). Both lakes together constitute at present the largest lacustrine system in the island. A temperate oceanic climate is characteristic of the archipelago, with mild temperatures, a rainfall regime with a strong seasonal cycle and large interannual variability, high relative air humidity, and frequent strong winds (Hernández et al., 2016). Those conditions are driven by oceanic (strength and position of the Azores Current) and atmospheric (semi-permanent high-pressure Azores Anticyclone) factors (Volkov and Fu, 2010). Thus, when the anticyclone migrates northerly or is weaker, generally during the autumn-winter period, the archipelago may be crossed by the North Atlantic storm tracks resulting in heavy rainfalls over it. Conversely, in the spring-summer period, the strengthened anticyclone blocks the storminess path (Santos et al., 2004). New insights, focused on the large-scale climate variability modes of the North Atlantic, revealed that the North Atlantic Oscillation (NAO) and the Atlantic Multidecadal Oscillation (AMO) exert a strong influence on the Azorean climate variability. Thus, seasonal and interannual variability is mainly due to the NAO influence (Andrade et al., 2008; Cropper and Hanna, 
2014; Hernández et al., 2016), but at decadal and longer time scales, the AMO also becomes relevant (Yamamoto and Palter, 2016; Hernández et al., 2017).

The main physiographic and limnological variables of Lake Azul and Lake Verde are summarized in Table 1. A generalized process of eutrophication has been observed in Lake Azul since 1987 (Cruz et al., 2015). Primary productivity at present is governed by cyanobacteria and, secondarily, by diatoms and cryptophytes. Diatoms reach maximum abundances during autumn-winter and spring, with Asterionella formosa Hassal, Aulacoseira ambigua (Grunow) Simonsen, A. granulata (Ehrenberg) Simonsen, Fragilaria crotonensis Kitton, F. cf. tenera, Ulnaria ulna (Nitzsch) Compêre and U. delicatissima var. angustissima (Grunow) Aboal and P. C. Silva as the main dominant taxa (Gonçalves, 2008; Pereira et al., 2014). At present, hydrophyte communities are mainly composed of invasive species such as Egeria densa Planch., Elodea canadensis Michaux. and Nymphaea alba Linnaeus (Gonçalves et al., 2013). The originally fishless condition of the Azorean lakes was modified in the late $18^{\text {th }}$ century, when different taxa of cyprinids and salmonids were introduced and stocked (Valois-Silva, 1886; Vicente, 1956; Flor de Lima, 1993; Raposeiro et al., 2017).

\section{Materials and methods}

In September 2011, fifteen sediment cores (AZ11) were recovered in Lake Azul (Fig. 1) using a UWITEC ${ }^{\odot}$ corer $(\varnothing 60 \mathrm{~mm})$ installed in a UWITEC ${ }^{\odot}$ platform raft following two transects: SW-NE direction (transect A) and W-E direction (transect B). Cores were split longitudinally into two halves and imaged using a high-resolution digital photographic camera installed in the Avaatec XRF core scanner (University of Barcelona). A detailed description of colors, textures and sedimentary structures was performed. Smear slides

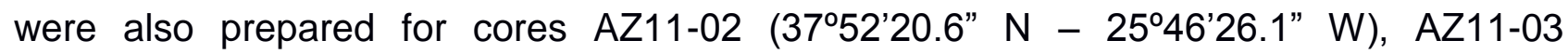




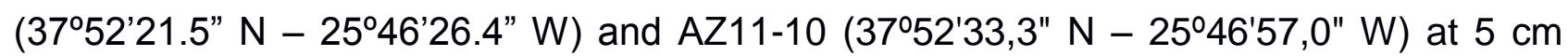
intervals and examined to define facies and lithostratigraphic units. The cores were correlated using the defined sedimentary facies and key beds.

The core AZ11-02 (133 cm long) from transect B, sampled at the deep offshore plain (25.1 m of water depth), was selected as representative of the hemipelagic sedimentation environment and used for the study of diatom assemblages. To ensure that the upper sediments were recovered, we checked diatom analysis on a short gravity core taken in 2006 in a location very close to the deep offshore plain of Lake Azul (AZ06 (37052'16.05" N - 2546’30.68” W), 62 cm long, Fig. 1; Gonçalves, 2008). Because clear comparable changes in diatom relative abundance data occur in both cores, tie-in levels could be defined, especially using the trends in the relative abundances of Aulacoseira spp. and Psammothidium abundans f. rosenstockii (Lange-Bertalot) Bukhtiyarova (see the diatom diagram in the Results section). The resulting stratigraphic correlation allowed the construction of a composite record referred in the text hereafter as the composite column. This correlation showed a lack of correspondence between the diatom assemblages found at the top of cores AZ06 and AZ011-02, allowing us to estimate that the first $\sim 30 \mathrm{~cm}$ of AZ11-02 were not recovered in the field.

Total carbon (TC), total nitrogen (TN), and isotopic composition of bulk organic matter $\left(\delta^{13} C_{\text {org }}\right.$ and $\left.\delta^{15} N_{\text {org }}\right)$ determinations were performed in core AZ11-02 using a Finnigan delta Plus EA-CF-IRMS spectrometer at Center Científics i Tecnològics of the Universitat de Barcelona (CCiTUB). Previous analyses by X-ray diffraction showed negligible amounts of carbonates in the samples; consequently, TC was considered to be equal to total organic carbon (TOC) (Raposeiro et al., 2017). TOC and TN results are expressed as percent values of the sediment dry weight. The atomic ratio of TOC/TN was calculated and corrected according to Talbot (2001) to discriminate inorganically bound nitrogen content from TN. From here on, the TOC/TN ratio is therefore referred to as TOC/TN ${ }_{\text {corr. }}$ Fluxes of 
TOC into the sediments have also been estimated in the form of mass accumulation rate (MAR, $\mathrm{mg} \mathrm{cm}^{-2} \mathrm{yr}^{-1}$ ) by multiplying their concentrations by the sediment dry densities and sedimentation rates at each depth. For the calculation of dry bulk densities, the samples were dried to remove free water. The isotopic composition of sediment organic matter was determined, and isotopic values are reported in the conventional delta-notation in per mil (\%o) relative to the Pee Dee Belemnite (PDB) carbon and atmospheric nitrogen $\left(N_{2}\right)$ standards.

Diatom analysis was performed following standardized procedures (Renberg, 1990). Slides were mounted with $\mathrm{Naphrax}^{\odot}$ mountant, and at least 400 valves per sample were counted at X1000 using a Nikon Eclipse 600 microscope with Nomarski differential interference contrast optics. Identifications of taxa were based on standard sources (e.g., Krammer and Lange-Bertalot, 1986-1991; Lange-Bertalot, 2000-2013), and contrasted with previous studies made on the Azores archipelago (Gonçalves et al., 2010). Taxa were grouped, according to their habitat preferences, as allochthonous (aerophilic) or autochthonous (euplanktonic, facultatively planktonic or tychoplanktonic, and benthic). Raw valve counts were converted to percentage abundance data. Statistical analyses were carried out on a diatom relative abundance matrix of those taxa attaining an abundance of more than $>5 \%$ in at least one sample. Samples which had sum abundances of allochthonous taxa reaching at least $5 \%$ were excluded from the analyses $(n=37)$. Diatom abundances from the remaining 77 samples were transformed by squareroot transformation prior statistical analysis. The definition of the main Diatom Assemblage Zones (DAZs) was performed using stratigraphically constrained cluster analysis based on squared Euclidean dissimilarity (CONISS, Grimm, 1987), as implemented in Psimpoll 4.10 (Bennett, 2002). Zonations with variances that exceeded the values generated by a broken-stick model of the distribution of variance were considered to be statistically significant (Bennett, 1996). A detrended correspondence analysis (DCA) was performed to 
measure the length of the main environmental gradient, which recommended the use of a linear model of ordination (principal component analysis; PCA) to determine the environmental drivers in the composition of the diatom assemblages. Both DCA and PCA were performed with the CANOCO 4.5 software (ter Braak and Smilauer, 1998).

A new age-depth model was constructed for the composite column (cores AZ-06 + AZ11-02), updating the previously available model which was restricted to core AZ11-02 (Raposeiro et al., 2017; Rull et al., 2017), and taking into account the non-recovery of the upper sediments of this core. This new model is based on linear interpolation of the available ${ }^{210} \mathrm{~Pb}$ profile for the AZ06 core (Gonçalves, 2008), the radiocarbon data from the AZ11 cores (Table 2), and several independent tie-in points. All ${ }^{14} \mathrm{C}$ ages were calibrated to calendar years (cal CE) using the CALIB 7.1 software (Stuiver and Reimer, 1993), and the latest INTCAL13 curve (Reimer et al., 2013).

\section{Results}

\subsection{Lithological units and sedimentary facies}

Facies analysis from cores retrieved in 2011 resulted in the definition of nine facies and eight sedimentary units for the entire basin (Fig. 2; definition also followed by Raposeiro et al., 2017 and Rull et al., 2017). These facies have been differentiated by lithology, texture, color, lamination characteristics, and shards content. Offshore sedimentary facies of the composite column have been grouped in 4 lithological units as follows:

Unit 1 (base-132 cm) is composed of gray tephra deposits (ash and lapilli) (Facies VS) from the P17 eruptive episode (Queiroz et al., 2008). These volcaniclastic deposits are usually interbedded by some thin layers of gray lacustrine muds in the deep plain. Cores taken during the 2011 survey indicate that this unit extends to the entire lake bottom area. 
Unit $2(132-114 \mathrm{~cm})$ is deposited above Unit 1 in the deep plain and rise zones of the lake. This unit is made up of banded-to-laminated gray muds (Facies E). These deposits were transported to the lake by runoff eroding volcanic ashes deposited in the catchment from the same eruptive episode that deposited Unit 1.

Unit $3(114-90 \mathrm{~cm})$ is recorded above Unit 2 and is mainly composed of greenish/yellowish brown laminated to banded muds (Facies C) deposited by decantation of fine-grained particles forming plumes of the surface and/or subaquatic nepheloid layers in the lake during short-term regular rains. These deposits intercalate some brown mud horizons enriched in shard particles (Facies B) that could be added to the suspended material by ash fallout from minor or distal eruptive episodes. Moreover, this unit intercalates dark brown mud layers rich in terrestrial plant remains, but poor in diatoms (Facies D). The composition and short lateral extent of layers of facies $D$ indicate that they correspond to subaquatic lobes deposited by flood events, likely during heavy rain episodes.

Unit 4 (90 cm-top) is deposited above Unit 3 and it is mainly composed of brown massive to poor laminated mud (Facies A) transported and deposited in a process similar to facies $\mathrm{C}$. These muds also intercalate dark brown mud layers rich in terrestrial plant remains corresponding to lobular deposits (Facies D).

\subsection{Chronology}

Available ${ }^{210} \mathrm{~Pb}$ data from core AZ06 (Gonçalves, 2008) and non-post-bomb radiocarbon ages of the AZ11 cores (Table 2, Fig. 3, Supplementary Materials) were used to construct the age-depth model of the composite column which best fitted with events of independently known age. The radiocarbon age at the bottom of the sequence was 
obtained immediately above the basal tephra, yielding $690 \pm 30 \mathrm{yr} \mathrm{BP}$, almost exactly fitting with the age previously estimated for the P17 eruptive episode of $663 \pm 105{ }^{14} \mathrm{C} \mathrm{yr}$ BP (Shotton and Williams, 1971). By contrast, the basal flood layer of Unit 4 yielded a ca. $100 \mathrm{yr}$ difference when dated in cores AZ11-02 (c. $1770 \mathrm{CE}$ ) and AZ11-03 (c. $1870 \mathrm{CE}$ ) (Fig. 3, Supplementary Materials). Comparison of the estimated and known dates for the first appearances in the pollen record of AZ11-02 (Rull et al., 2017) of the exotic Cryptomeria japonica and Pinus spp., resulted in a much closer fit of the flood event dated to 1870 CE in core AZ11-03 rather than 1770 CE dated in core AZ11-02 (Fig. 3), so the former was preferred for the final age model. Chronology for the upper sediments is based on the ${ }^{210} \mathrm{~Pb}$ data from core AZO6 because of the more reliable use of ${ }^{137} \mathrm{Cs}$ tie-in points (Gonçalves, 2008), instead of using a single post-bomb radiocarbon age of core AZ11-02 (Table 2).

In conclusion, the new age model therefore differs from the previously published (Raposeiro et al., 2017; Rull et al., 2017) in a) the use of new ${ }^{210} \mathrm{~Pb}$ dates of core AZ06 which provide a chronology for the non-recovered history in core AZ11-02, and b) a reassessment of the age of the basal flood event of Unit 4. Comparison of chironomid (Raposeiro et al., 2017), pollen (Rull et al., 2017), and diatom (this work) zones using the old and definite age models is shown in the Supplementary Materials.

\subsection{Diatom assemblages}

Diatom taxa with abundances higher than $5 \%$ in at least one sampling level were plotted in stratigraphic order for the composite column (Fig. 4). Except for the lacustrine muds corresponding to the facies VS at the base of the core (Unit 1), benthic diatoms dominated the assemblages from approx. 140 to $40 \mathrm{~cm}$. Above $40 \mathrm{~cm}$ planktonic diatoms (mainly Aulacoseira spp. and also, higher up, Asterionella formosa and $F$. crotonensis) began their 
dominance. Those levels close to or coincident with flood events (facies D) had a remarkably lower total valve content due to the massive short-term deposition of terrestrial sediments. Furthermore, these levels were characterized by high relative abundances of aerophilic diatoms, mainly from the genera Diadesmis and Diploneis (Fig. 4), indicating that any lacustrine signal given by the autochthonous taxa would be masked by the effects of both the sedimentary dilution and by the incorporation of allochthonous valves during the flood events. To avoid interferences in the lacustrine signal, data from all the volcanic levels in Unit 1 (base-132 cm), as well as those with high TOC/TN geochemical results below) and/or sum abundances of aerophilic diatoms $>5 \%$, were excluded from any further statistical analyses.

The resulting broken-stick model of the distribution of variance allowed us to identify four statistically significant DAZs (AZU-1 to AZU-4) based on CONISS (Table 3 and Fig. 4). DAZ AZU-2 was also divided into two subzones.

DCA results indicated a linear response of the diatom assemblages to the environmental gradients, since the longest gradient was 2.7 SD units (Leps and Smilauer, 2003), and a PCA was therefore performed to interpret the underlying environmental variables explaining the composition of the diatom assemblages.

The first two axes of the PCA explained $66.1 \%$ of the total variance (Fig. 5). The first axis (PC1, 42.4\% of the variance), places benthic diatoms (mostly epipelic and motile), such as Navicula notha J. H. Wallace, Eolimna sp1, Nitzschia spp. aff. pseudofonticola, $N$. lacuum Lange-Bertalot or N. perminuta (Grunow) M. Peragallo, on the positive side of the plot. The negative side is occupied by some euplanktonic and eutrophic taxa as $A$. ambigua, F. crotonensis and Asterionella formosa. The second axis (PC2, 23.7\% of the variance), shows the highest negative values for the euplanktonic. $A$. ambigua, Asterionella formosa, and F. crotonensis, whereas periphytic diatoms, mainly Stauroforma 
exiguiformis (Lange-Bertalot) R.J. Flower, V.J. Jones \& Round, Encyonopsis spp. aff. cesatii, Adlafia minuscula var. muralis (Grunow) Lange-Bertalot, Pseudostaurosira brevistriata (Grunow) D.M. Williams \& Round, P. abundans f. rosenstockii, and the Fragilaria capucina group, exhibit positive scores. The resulting biplot of PC1 vs. PC2 shows three main groups of samples corresponding to the DAZs a) AZU-1, b) AZU-2 and c) AZU-3 + AZU4 (Fig. 5).

Variations in the two first principal components through the sedimentary sequence were plotted on the stratigraphic chart (Fig. 6). PC1 shows a progressive decrease from AZU-1 to AZU-4, stabilizing at approx. $27 \mathrm{~cm}$ until the top of the core. PC2 shows an increasing trend from the immediately post-eruptive phase at approx. $140 \mathrm{~cm}$ until $70 \mathrm{~cm}$, decreasing thereafter.

\subsection{Geochemical proxy data}

Very low percentages of $T O C$ and $T N$ characterize Units 1 to 3 , with values ranging between 0.18 to $1.13 \%$ and 0.05 to $0.12 \%$, respectively (Fig. 6). Both proxies exhibit a net increase in Unit 4 from 90 to $40 \mathrm{~cm}$ with values ranging from 0.81 to $3.53 \%$ and 0.08 to $0.34 \%$ for TOC and TN, respectively. TOC MAR oscillate between 0.21 and $14.86 \mathrm{mg} \mathrm{C}$ $\mathrm{cm}^{-2} \mathrm{yr}^{-1}$ from the base to $29 \mathrm{~cm}$, respectively. TOC and TOC MAR exhibit a similar pattern from the base of the core to $64 \mathrm{~cm}$ depth.

TOC and TN percent values show a high linear correlation $(r=0.94, p<0.01)$, and because of this, the correction suggested by Talbot (2001) was used to discriminate the fraction of $\mathrm{TN}$ not attributable to TOC. Thus, the $\mathrm{TOC} / \mathrm{TN}_{\text {corr }}$ atomic ratio allowed us to separate those levels with allochthonous organic matter (Facies D) more efficiently. Facies $A, B$ and $C$ show values of $T O C / T N_{c o r r}$ between 8 and 13 , a range that is typical of organic 
matter of mixed but mainly lacustrine origin (Meyers and Teranes, 2001). Facies $D$ shows values ranging between 14 and 25, characteristic of the larger influence of C3 land plants, which is consistent with the flood event origin of these sediments.

The $\delta^{13} \mathrm{C}_{\text {org }}$ curve shows, in general, an inverse correspondence with the TOC/TN $\mathrm{N}_{\text {corr }}$ curve (Fig. 6). This is more clearly manifested in facies $D$ deposits, where $T O C / \mathrm{TN}_{\text {corr }}$ values are always higher than 14 . Units $1,2,3$, and the bottom half of Unit 4, when the last flood event was recorded between 69 and $75 \mathrm{~cm}$, show $\delta^{13} \mathrm{C}_{\text {org }}$ values ranging between 27.5 and $-22.5 \%$. A significant rise is observed between 68 and $40 \mathrm{~cm}$, when values oscillate between -26.4 and $-22.4 \%$. From here to $29 \mathrm{~cm}$, the range shortens from -25.9 to $-23.2 \%$. Despite the lack of correspondence between TOC and $\delta^{13} \mathrm{C}_{\mathrm{org}}$ throughout most of the core, trends exhibited from $68 \mathrm{~cm}$ are quite similar, and remarkably decreasing in the uppermost values in both proxies.

The $\delta^{15} \mathrm{~N}_{\text {org }}$ values range between $-0.02 \%$ and $3.09 \%$, showing lower values (close to 0 ) in Facies D terrestrial sediments or levels close to these facies. The lacustrine levels of Units $1,2,3$, and the bottom half of Unit 4 to $68 \mathrm{~cm}$ are characterized by oscillating values ranging from 0.21 to $2.84 \%$. A slight upwards decreasing trend to values close to 0 is recorded towards the top of the core AZ11-02.

\section{Discussion}

\subsection{Environmental gradients explaining diatom assemblage composition}

Results of PCA indicate the two main environmental components driving the long-term changes in diatom composition in Lake Azul. The negative scores exhibited along PC1 by the eutrophic and euplanktonic species A. ambigua, F. crotonensis or Asterionella formosa (e. g., Reynolds et al., 2002) vs. the high positive values of benthic species such as $N$. 
notha, N. lacuum or N. perminuta, of predominantly oligotrophic affinities (e. g. Krammer and Lange-Bertalot, 1986-1991), suggest that this main axis is related with a trophic gradient (Fig. 5). The plot of samples on the space defined by the PC1 vs. PC2 (Fig. 5) shows two extremes represented by the oligotrophic conditions and exclusive benthic production of DAZ AZU-1 (1290-1475 CE) vs. the meso- to eutrophy characteristic of the pelagic production of DAZs AZU-3 and AZU-4 (1930-2006 CE).

The biplot of PC1 vs. PC2 (Fig. 5) also shows on the positive side of PC2 diatoms performing a large array of life form strategies, ranging from purely euplanktonic (e. g., A. granulata), tychoplanktonic (e. g., Pseudostaurosira elliptica (Schumann) Edlund, Morales and Spaulding, P. brevistriata), epiphytic (e. g., P. abundans f. rosenstockil), to sediment dwelling (e. g. A. minuscula var. muralis, E. sp. aff. cesatii). Most of the positive sample scores correspond to DAZ AZU-2, an assemblage interpreted as related with an increase in the relative extension of shallow littoral vs. deep lacustrine habitats (Table 3). By contrast, the negative side of the plot shows diatoms behaving only as euplanktonic ( $A$. ambigua, F. crotonensis, Asterionella formosa) or sediment dwelling (Eolimna sp1, $\mathrm{N}$. notha, N. lacuum and N. perminuta). PC2 is therefore understood as reflecting a gradient in microhabitat availability, whose maximum would be reached in DAZ AZU-2 (1475-1930 $\mathrm{CE})$.

\subsection{Main ecological phases in Lake Azul}

The multidisciplinary study of the recent sedimentary record of Lake Azul reveals the complex overlapping of natural and anthropogenic forcings that drove the evolution of this system in the last ca. $720 \mathrm{yr}$. According to the obtained multiproxy information the lake went through six different environmental phases, as described below. 


\subsubsection{Phase I. Basal zone - eruptive phase (P-17 eruption)}

The recent history of Lake Azul begins with a volcanic catastrophic event indicated by the deposition of a thick tephra layer (facies VS), recorded in Unit 1. This event corresponds to the Caldeira Seca P17 volcano eruption, which accumulated tephra deposits in extensive areas of the Sete Cidades caldera (Cole et al., 2008). Although some exceptional fallout of diatoms transported into the volcanic eruption plume cannot completely be disregarded (Van Eaton et al., 2013), high abundances of the euplanktonic and eutrophic $A$. granulata in muddy lacustrine sediments interbedded between volcanic deposits (facies VS) (Fig. 4) are more easily explained by sedimentation in situ around the time of the eruption. They would correspond to the most recent phase of the eruption (phase L3 according to Cole et al., 2008), which would have accumulated 4-20 m of lapilli in the lake's bottom surface. Diatoms of the genus Aulacoseira are characteristic of wellmixed waters necessary to maintain their buoyancy and relatively high nutrient conditions (Hall and Smol, 2010). The species A. granulata is accompanied during this phase by Nitzschia valdestriata Aleem and Hustedt, a benthic diatom which has been reported as aerophilic (e.g., Robinson, 2004); thus, its presence in Unit 1 can indicate transport from the emerged zones in the margins to the innermost areas of the lake. The diatom assemblage found in this unit (Fig. 4) would therefore represent the existence of a moderately deep, well mixed, and meso to eutrophic lake, approx. at the time of ash deposition, with a significant contribution of allochthonous materials. This interpretation is reinforced by moderate $\mathrm{TOC} / \mathrm{TN}_{\text {corr }}$ values of approximately 15 , along with low values of $\delta^{13} \mathrm{C}_{\text {org }}$, which are indicative of isotopically light terrestrial organic matter (Meyers and Teranes, 2001). Whereas the dominance of Aulacoseira has been found as typical of the mid-depth zone across lake water-depth gradients elsewhere (e. g. Kingsbury et al., 2012), the study of pollen and non-pollen palynomorphs (NPPs) in Lake Azul suggested shallower water conditions (Rull et al., 2017). This circumstance might imply that the lake 
was subjected to short-term fluctuations in water levels at this time.

The main ecological consequence of the major phase of the P17 volcanic eruption was the replacement of a diatom community that included $A$. granulata and $N$. valdestriata by a new one controlled by benthic attached life forms, mainly Achnanthidium minutissimum (Kützing) Czarnecki. Tephra deposition can involve a disruption in the internal recycling of $\mathrm{P}$, which is more significant in lakes with small catchment areas relative to the total lake area (Barker et al., 2000; Telford et al., 2004), such as Lake Azul, with a total lake area of $3.59 \mathrm{~km}^{2}$ vs. a lake drainage area of $15.35 \mathrm{~km}^{2}$ (Fig. 1; Table 1). This, plus a significant increase in Si loading associated with the deposition of tephras, would have greatly altered the Si:P ratio, prompting the replacement of the previous diatom communities by new opportunistic species (Kilham et al., 1986). The species $A$. minutissimum has been documented as a pioneering $r$-strategist on disturbed aquatic environments (Peterson and Stevenson, 1992; Stevenson et al., 1996; Leira et al., 2015) with a strong affinity for waters with a high Si content and usually attaching to unspecific substrates (Stenger-Kovács, et al., 2006). Moreover, this taxon is referred as a good indicator of low organic content in the water column (Potapova and Hamilton, 2007). High abundances of $A$. minutissimum would therefore indicate that, after tephra fallout, the lapilli and ash sterile materials which covered the lake bottom were colonized by a new diatom community that restarted ecological succession. This situation was also accompanied by low values of TOC and TN in the sediments, as well as of TOC MAR, which are maintained in the following phase, suggesting an oligotrophication event.

\subsubsection{Phase II: moderately shallow oligotrophic lake (ca. 1290-1480 CE)}

During this phase, which is coincident with DAZ AZU-1 $(125-90 \mathrm{~cm})$, coarse-grained tephra sediments of Unit 1 were replaced by fine-grained muddy sediments from Units 2 (Facies $\mathrm{E}$ ) and 3 (Facies $\mathrm{B}$ and $\mathrm{C}$ ). The reduction in grain size induced a change to an 
epipelic-dominated diatom assemblage characterized by high abundances of Eolimna sp1, together with Navicula s. I. and Nitzschia spp. (AZU-1, Fig. 4). Extensive growth of epipelic diatom communities after tephra deposition, when the sediment grain-size of the lake bottom surface is adequate, has also been reported elsewhere (e. g., Harper et al., 1986; Telford et al., 2004), indicating the progression of the ecological succession. The referred taxa are also typical of both shallow and mid-depth zones of lakes where light can reach the bottom (Wang et al., 2012). These characteristics, and the minor role of euplanktonic and tychoplanktonic taxa during this phase, would be indicative of a moderately shallow water environment (Wolin and Stone, 2010), which according to the pollen and NPPsbased water level reconstruction (Rull et al., 2017) should be below 15 m. Maximum PC1 values are recorded during this phase, suggesting that oligotrophic conditions were maintained over the approximately $200 \mathrm{yr}$ of this phase, according also with the low values of TOC and TOC MAR. Maximum percent abundances of Nitzschia spp. are also recorded during this phase, almost disappearing thereafter. This genus is reported to be good at growing at low P supply (Kilham et al., 1986), and many species are facultative or obligate nitrogen heterotrophs (Werner, 1977; Kilham et al., 1986). This observation suggests that although tephra deposition inhibited complete $\mathrm{P}$ recycling the lake was probably not $\mathrm{N}$ limited.

\subsubsection{Phase III: deep oligotrophic lake (ca. 1480-1870 CE)}

The most significant feature of this phase, corresponding to sedimentation of the lower part of Unit 4 (DAZ AZU-2a, $90-75 \mathrm{~cm}$ ), is the flooding of the platform ramp associated with a water level increase, which allowed a large relative increase in littoral vs. pelagic environments (Fig. 1). Chronostratigraphical, historical and diatom data support this hypothesis. The stratigraphical chart shows the first appearance of lacustrine sediments in the ramp environment radiocarbon dated in core AZ11-07 to ca. 1545 CE (Fig. 2). This position is located at approximately $500 \mathrm{~m}$ from the limit between the ramp and the slope 
(Fig. 2), pointing to an earlier flooding of the ramp. According to the available chronicles of Gaspar Frutuoso (1522-1591), the lake had, at the time, a maximum depth of 7-8 fathoms (Frutuoso, 1977), that would equal $\sim 15-17 \mathrm{~m}$. The lake bathymetric map shows an extensive area of the ramp that would be subaereally exposed (Fig. 1), and this agrees with the description of a large "beach" made up of "sterile sands" (Frutuoso, 1977). Flooding of the ramp brought a sharp change in the diatom communities. Fragilarioid taxa (mainly P. brevistriata and P. elliptica) became clearly dominant (DAZ AZU-2a, Fig. 4). These taxa are early colonizers characteristic of the shallow-water littoral zone of a wide variety of water bodies under conditions of environmental instability (Reed et al., 1999). Although their appearance in Lake Azul could be related to a deeper water column due to their tychoplanktonic character, increased availability of shallow littoral habitats when the flooding occurred was probably a decisive contributing factor for their expansion (Stone and Fritz, 2004; Wigdahl et al., 2014). Their rise is also coincident with the increase of Myriophyllum alterniflorum (Rull et al., 2017), a submerged macrophyte characterized by a high number of thin leaves that largely increase the colonizable area for periphytic microalgae (Cattaneo and Kalff, 1980). A complex permanent periphytic community was therefore established in the lake littoral zone for the first time (Fig. 6). Compared to Phase II, when both oligotrophy and a steeper lake bottom resulted in a low diversification of the diatom assemblages, the flooding of the platform ramp in Phase III resulted in an increased area of benthic vs. planktonic habitats. As a result, life-form strategies adopted by diatoms diversified in Phase III, as indicated by the high recorded values of PC2.

Both regular flood events from the lake catchment and the effects of deforestation during this period (Rull et al., 2017), probably also brought episodic high nutrient concentrations that allowed the short-term growth of eutrophic euplanktonic diatoms ( $A$. ambigua and $A$. granulata), which appear for the first time since the reset of the lake after the P17 volcanic episode. Both the increase in the TOC/TN ratio and negative excursions 
of $\delta^{13} \mathrm{C}_{\text {org }}$, associated with the floods, point to a significant delivery of terrestrial organic matter to the lake (Meyers and Teranes, 2001). The Nitzschia spp. sharp decline during this phase suggests that this increased nutrient availability altered the dynamics of the $\mathrm{P}$ and $\mathrm{N}$ cycles within the lake, decreasing the N:P ratio. Although TOC and TOC MAR values increased compared to the previous phase, they still remained low, suggesting that oligotrophic conditions persisted during this stage, as indicated also by the high values of PC1.

5.2.4. Phase IV: deep oligotrophic lake and transition to a new trophic state (ca. 1870 1940 CE)

During the sedimentation of mid-to-upper part of Unit 4 (DAZ AZU-2b, $75-41 \mathrm{~cm}$ ), TOC and TN follow the steady uprising trend since the ecological reset after the Caldeira Seca P17 eruption, which suggests an increase in productivity. Most of the organic matter produced has an algal origin, according to the $\mathrm{TOC} / \mathrm{TN}_{\text {corr }}$ values (Meyers and Teranes, 2001). Moreover, the still low values of TOC and TOC MAR, suggests that the water column, despite the increase in productivity, remained oligotrophic. This would be in accordance with the large light availability at the time $\left(19^{\text {th }}\right.$ century), indicated by the high abundances of the charophytes Chara fragilis Desvaux and Nitella tenuissima (Desvaux) Kützing (Trelease, 1897; Cunha, 1939), the presence of the typical oligotrophic chrysophycean Dinobryon sertularia Ehrenberg (Barrois, 1896), and the recorded high abundances of desmids (Bohlin, 1901).

Despite the lake still being oligotrophic, the proxy data suggest that during this phase, a long-lasting ecological change commenced, indicated by heavier $\delta^{13} \mathrm{C}_{\text {org }}$ values and the reduction in $\mathrm{TOC} / \mathrm{TN}_{\text {corr }}$ associated with a lesser flood events occurrence, with the exception of the ca. $1870 \mathrm{CE}$ event recorded at the start of this phase. Additionally, the correspondence found during this phase between the TOC and $\delta^{13} \mathrm{C}_{\text {org }}$ curves, which up to 
this time were uncoupled, points to a change in carbon fractionation compared to the previous phases. This change co-occurs with the remarkable landscape reconfiguration due to the massive introduction of the exotic arboreal taxa $C$. japonica and Pinus spp. in the catchment after 1850 CE (Rull et al., 2017). Restricted delivery of terrestrial organic matter to the lake due to the increase in tree cover in the catchment would induce heavier $\delta^{13} \mathrm{C}_{\text {org }}$ values and a reduction in the TOC/TN $\mathrm{N}_{\text {corr }}$ ratio (Meyers and Teranes, 2001).

However, not only a more restricted delivery of terrestrial organic matter to the lake could induce heavier $\delta^{13} \mathrm{C}_{\text {org }}$ values but also the increase of in-lake productivity (Meyers and Teranes, 2001), which is also indicated by the net rise in TOC values (Fig. 6) and by the regular presence of the euplanktonic and meso- to eutrophic diatoms of the genus Aulacoseira (Fig. 4). The necessary nutrient enrichment that triggered this increase in productivity and the presence of Aulacoseira could not be due to the delivery of materials from the catchment, as indicated by the decrease in the $\mathrm{TOC} / \mathrm{TN}_{\text {corr }}$ ratio. Two alternative mechanisms can be invoked to explain nutrient enrichment. First, fish introductions which started in the late $18^{\text {th }}$ century in this formerly fishless lake could intensify internal nutrient release in the lake, especially the stockings of cyprinids, such as Goldfish Carassius auratus Linnaeus introduced in 1792 CE (Valois-Silva, 1886), and Carp Cyprinus carpio carpio Linnaeus, introduced in 1890 (Vicente, 1956). Their feeding activity is known to have a strong effect on the release of nutrients to the water by sediment resuspension (e.g., Richardson et al., 1995). This concentration effect was probably enhanced by the development at this time of an oxygen-depleted deep hypolimnion on a seasonal basis, according to the chironomid data (Raposeiro et al., 2017), which would highly enrich the bottom waters with $\mathrm{P}$ (Cohen, 2003). The primary role that internal nutrient recycling induced by fish stockings could have played is in accordance with the known fact that the major driver of eutrophication in this lake is, at present, internal P-loading (Cruz et al., 2015). A second mechanism could be nutrient injection from Lake Verde overflow which 
probably increased total nutrient concentration in Lake Azul after the connection between the two lakes in 1877 CE (Andrade, 2003).

The multiproxy data suggest a long-term gradual process of eutrophication to a new trophic state during this phase, mainly induced by sediment disturbance after fish introductions and nutrient inputs from Lake Verde overflow after its connection in 1877 CE.

\subsubsection{Phase V: deep mesotrophic lake (ca. 1940-1995 CE)}

In the upper part of Unit 4 (DAZ AZU-3, 41-11 cm), all proxies reveal a major and sudden change in the ecosystem. From ca. 1940 to 1995 CE, there is a sharp shift in the diatom assemblages, which now become dominated by the euplanktonic and eutrophic $A$. ambigua (AZU-3, Fig. 4). Although tychoplanktonic diatoms subdominate the assemblages, benthic taxa significantly decrease. Lighter values of $\delta^{13} \mathrm{C}_{\text {org }}$, not related with flood events, also support the hypothesis of a larger pelagic production compared to the previous phase, since periphyton is usually enriched in ${ }^{13} \mathrm{C}$ compared to phytoplankton due to a higher $\mathrm{CO}_{2}$ limitation of primary producers in the littoral zone (France, 1995). In addition, organic carbon MARs attain maximum values, indicating increased productivity. The lack of correspondence between the TOC MAR and TOC, which decrease during this phase, reflects the increased relative importance of biogenic silica in the sediments associated with larger biosiliceous productivity. The excess of nutrient loads from intensive fertilization and livestock manure, especially since the 1960s (Gonçalves, 2008; Cruz et al., 2015), constitutes the main factor responsible for the detected environmental change. They not only led to increased eutrophication, but probably also prompted the shift from a benthic to pelagic-dominated environment because of the shading effect of phytoplankton over benthic algae also recorded in other Azorean lakes (Buchaca et al., 2011). This change is accompanied by the significant decline in Myriophyllum alterniflorum, which already started in the previous phase (Rull et al., 2017), a macrophyte sensitive to 
eutrophication and turbidity (Kohler and Labus, 1983).

\subsubsection{Phase VI: deep meso-eutrophic stratified lake (ca. 1995-2006 CE)}

Although dominant pelagic production still characterizes this phase recognized at the uppermost part of Unit 4 (DAZ AZU-4, 11-0 cm), there is an important reduction in $A$. ambigua, which now co-dominates the diatom assemblages with Asterionella formosa and Fragilaria cf. tenera. There is also a peak of the euplanktonic $F$. crotonensis during this phase. This assemblage of $A$. ambigua, Asterionella formosa and $F$. crotonensis has been reported elsewhere as typical of eutrophic light-limited conditions (Reynolds et al., 2002; Saros and Anderson, 2015). Both Asterionella formosa and F. crotonensis have similar resource requirements (Hobbs et al., 2011), being indicative of modest eutrophication by $\mathrm{P}$ enrichment in temperate lakes (Saros et al., 2005). Changes in the TN:TP ratios can explain the shifts in the diatom assemblages and the recent dominance of cyanobacteria in the lake (Gonçalves, 2008; Cruz et al., 2015), but the response of phytoplankton communities to changes in water chemistry are many times site-specific (e.g., Saros et al., 2005). Moreover, both $\mathrm{P}$ and $\mathrm{N}$ enrichment have been demonstrated to favor the development of cyanobacterial blooms in Lake Azul (Cruz et al., 2015). Alternatively, changes in thermal structure rather than changes in stoichiometric ratios can be behind significant shifts in the composition of phytoplankton in modern lakes (Mantzouki et al., 2018). Enhanced water column stratification associated with warmer temperatures could explain the decline in heavy diatom taxa such as Aulacoseira, which need well-mixed waters to thrive (Margalef, 1978). Water stratification would favor the development of $F$. crotonensis (Wolin and Stone, 2010), and the known dominance of cyanobacteria in the phytoplankton over diatoms for 10 months a year (Gonçalves, 2008) would put very fastgrowing species such as Asterionella formosa in the advantage (Reynolds, 2006). The data suggest that eutrophication increased during this phase, transforming lake's condition into a meso-eutrophic state, and that changes in the TN:TP ratio and/or enhanced 
stratification due to temperature increase were the main factors responsible of this change.

\subsection{Main long-term drivers of trophic status changes}

Paleoenvironmental reconstruction of Lake Azul for the approx. last $700 \mathrm{yr}$ allowed the identification of different potential natural (volcanism and climate) and human-induced drivers of change in its trophic status: a) eruptive volcanism, b) external nutrient loads from the watershed, c) changes in morphometry associated to lake-level rise, d) bottom-up and top-down trophic controls, e) changes in the water column mixing regime, and f) artificial fertilization derived from agricultural and farming activities.

The recorded ca. $700 \mathrm{yr}$ history of Lake Azul begins with the extreme Caldeira Seca P17 volcanic eruption of ca. 1290 CE (phase I) whose ashes deposited with a diatom assemblage of meso to eutrophic affinities. Although this sin-eruptive process makes unclear the existence of a pre-eruptive meso to eutrophic lake, the post-eruptive record shows the abrupt replacement of this diatom assemblage by another characteristic of oligotrophic conditions. This sharp shift in the diatom assemblages in Lake Azul points to a likely reset of the lake ecosystem due to the sedimentation of thick tephra deposits. This oligotrophication mediated by $\mathrm{P}$ limitation resembles that of Lake Massoko (Tanzania) following the deposition of a few centimeters-thick tephra (Barker et al., 2000). Although the magnitude of this event would be insignificant compared to the sedimentation of the several-meters-thick tephra layer P17 in Lake Azul, both cases seem to have experienced a similar process. Contrary to enhanced productivity after tephra deposition found elsewhere (e. g. Modenutti et al., 2013), the catastrophic nature of the Caldeira Seca P17 eruption implied settling of new pioneering biological communities which restarted ecological succession. The dominant benthic algal community also played a prominent role in maintaining oligotrophy in the following $200 \mathrm{yr}$ (1290-1480 CE, phase II), 
irrespective of several flood episodes (Facies D) that could potentially intensify allochthonous nutrient inputs. Despite their similar requirements, planktonic algae obtain nutrients exclusively from water, while periphytic algae, typical of the shallow water conditions during this period, can assimilate nutrients from both water and the sediment pool (Hansson, 1992). The dominance of periphytic communities during this phase would therefore have prevented the release of nutrients to support euplanktonic diatoms, maintaining oligotrophy in the lake, more severe in the pelagic environment. Moreover, the enhanced precipitation regime in São Miguel Island for this period (Hernández et al., 2017) and the probable denudation of the watershed by the eruption, which would favor large nutrient inputs to the lake, had no effect on aquatic primary productivity at the studied temporal resolution.

The period 1480-1870 CE (phase III) encompasses the extractive and transformative phases of human colonization which implied extensive deforestation in the archipelago (Connor et al., 2012; Rull et al., 2017). Despite geochemical and diatom data which indicate persistent allochthonous inputs due to forest clearance in the watershed, during approx. $400 \mathrm{yr}$ the lake did not significantly alter its oligotrophic condition. Although precipitation events might have contributed to very short-term flood events (Facies D, Figs. 3, 4 and 5), nutrient delivery was not sufficient for a sustained development of the eutrophic Aulacoseira spp. flora, which needs a more constant concentration of nutrients in the water column, as reported by Hall and Smol (2010). It was also during this period when a net water level rise, following regional more humid conditions (Hernández et al., 2017), flooded the platform ramp (Fig. 2), increasing the area of the epilimnion sediments with respect to the total volume of the epilimnion. Under these circumstances, recirculation of nutrients from the sediments to the epilimnion should be increased (Fee, 1979), prompting eutrophication. Yet, this ultimately natural eutrophication process did not significantly move Lake Azul from its oligotrophic condition during $400 \mathrm{yr}$, acting at a much slower pace 
compared to meso- to eutrophic paleo-lake systems, where significant changes in the area of the epilimnion sediments with respect to the total volume of the epilimnion also occurred (e.g., Bao et al., 2015). Oligotrophy was therefore maintained irrespective of the combined effect of man-induced allochthonous nutrient inputs associated to deforestation and the natural infilling with water which could have brought a situation of morphometric eutrophy as described by Rawson (1955).

Another morphometric threshold would be represented by the connection between Lake Azul and Lake Verde in 1877 CE, which is probably contemporary with the flood event of 1870 CE. It can be hypothesized that the much smaller water volume in Lake Verde would have favored higher nutrient concentrations, as at present (Table 1), and that connection of both lakes could induce a significant nutrient transfer to Lake Azul. Exotic species introduction in the lake is another factor which could have prompted any significant change in trophic conditions via top-down and bottom-up controls of the food web (McQueen et al., 1989). Data from Lake Azul indicate that the increase in productivity during the period 1870-1940 CE (phase IV), coincident with local drier and colder conditions (Hernández et al., 2017) that would diminish the delivery of nutrients from the catchment, as it is also indicated by the TOC/TN data, was likely due to both nutrient delivery from Lake Verde after connection took place and by internal nutrient recycling. Fish disturbance action favoring sediment resuspension was the most probable cause for the latter. Additionally, grazing activity by planktivore fishes, such as carp, imply an intensification of predation pressure on zooplankton, whose reduction, besides the mentioned intensified nutrient release from the bottom, results in increased phytoplankton biomass and productivity (Vanni, 2002). But these bottom-up (by sediment resuspension) and top-down (predation over zooplankton) effects by fish activity, as well as nutrient load from Lake Verde, had a quite limited action in Lake Azul. Compared to the major role that fish introductions had on the long-term pelagic nutrient enrichment of other Azorean lakes (Skov et al., 2010; 
Buchaca et al., 2011), the effects in Lake Azul were quite attenuated. Paleoenvironmental data from Lake Azul suggest that both fish introductions and Lake Verde overflow induced a gradual process of transformation, instead of a sudden non-linear ecological change ascribable to an ecological regime shift, as described by Lees et al. (2006). The oligotrophic inertia of the system was maintained for another $70 \mathrm{yr}$ because, either nutrient delivery from Lake Verde was low, or fish introduction did not induce enough return of $P$ from the sediments. This is in accordance with the suggestion that in oligotrophic lakes productivity is more limited by nutrient supply rather than by changes in trophic interactions (Schindler et al., 2001). It is not possible from our data to disentangle the relative importance of increased nutrient inputs from Lake Verde vs. enhanced nutrient recycling by fish activity in this gradual process of eutrophication.

The most significant trophic event since the likely reset of the P17 eruption (ca. 1290 $\mathrm{CE}$ ) occurred after $1940 \mathrm{CE}$ to the present (phases $\mathrm{V}$ and $\mathrm{VI}$ ), when the oligotrophic inertia of the lake was interrupted. The observed changes, mainly the sudden maximum increase of euplanktonic eutrophic diatoms, the reduction of hydrophytes in the recent pollen record (Rull et al., 2017), and, more recently, the dominance of cyanobacteria in the lake (Gonçalves, 2008; Cruz et al., 2015), indicate that the present-day status as a mesoeutrophic lake was reached during this period. Although eutrophication due to increased artificial nutrient input from the watershed was the main responsible for this major environmental change, other intervening factors need also be considered. It cannot be completely disregarded that part of the $\mathrm{N}$ enrichment influencing present-day phytoplankton composition in Lake Azul had an atmospheric origin (sensu Elser et al., 2009), but this is difficult to disentangle from the confounding effect of $\mathrm{N}$ loading from the catchment by human activities (as reported by Catalan et al., 2013). Likewise, increased thermal stratification could explain the shifts in phytoplankton composition, such as the decline in Aulacoseira species (e.g., Rühland et al., 2008), and the concurrent increase of 
other components, such as cyanobacteria (e.g., Mantzouki et al., 2018). The synergetic effect of, first, excess nutrient load and, second, reduced water turnover, could be behind the exacerbation of the symptoms of eutrophication (Jeppesen et al., 2014; Le Moal et al., 2019). This can be the reason why, despite some remediation measures such as surface runoff diversion, both monitoring (Cruz et al., 2015) and the paleolimnological (this study) data show that the lake is not experiencing at present a significant change in its trophic status.

Our results indicate that cataclysmic volcanism was the main driver in configuring Lake Azul ecology in the last ca. $700 \mathrm{yr}$. Previous studies on the long-term effects of deposition of thin distal tephra on biological communities have shown that these are usually shortlived (100-150 yr, Telford et al., 2004). Recovery can sometimes be very rapid, such as the case of oligotrophic Lake Galletué (Chile) after the deposition of a few $\mathrm{cm}$ thick tephra in 1957 CE which took just approx. 5 yr (Cruces et al., 2006) or the meso to eutrophic Lake Holzmaar (Germany) which lasted 10-20 yr maximum after the deposition of approx. $8 \mathrm{~cm}$ thick tephra (Lotter et al., 1995). Even catastrophic eruptions such as that of Mt. St. Helene (United States) in 1980 CE, which brought the virtual elimination of algae population in Lake Spirit, implied the quasi-recovery to the pre-eruptive conditions of this oligotrophic lake in approx. 30 yr (Larson et al., 2006; Gawel et al., 2018). Although it has been hypothesized that the long-term disruption of lake ecosystems can occur when biogeochemical cycling is interrupted after catastrophic volcanic events (Telford et al., 2004), few examples have been demonstrated in the literature (e. g., Barker et al., 2000). Lake Azul constitutes an example of such a disruption and of the gradual reestablishment of its pre-eruptive meso to eutrophic condition throughout $650 \mathrm{yr}$ only after artificial fertilization accelerated this process in the last decades.

A consequence of this primary role of volcanism as a driver in the ecological trajectory of Lake Azul is the potential ability or not of its diatom and bulk organic matter content to 
reconstruct paleoclimates in the region. Comparison with the paleoclimate data obtained from Lake Empadadas, located just 6 km away in São Miguel island (Hernández et al., 2017), shows the minor role of changes in nutrient delivery associated to precipitation variability in changing the trophic status in Lake Azul. Besides noteworthy differences in the size and morphometric characteristics of both basins which make Lake Empadadas more sensitive to any subtle precipitation regime change, the effects of the P17 eruption were irrelevant in this lake compared to Lake Azul. Contrary to the effects of the deposition of thin tephra layers which do not override the long-term changes due to climate change (e. g., Lotter et al., 1995; Telford et al., 2004; Egan et al., 2019), any climatic signature on productivity in Lake Azul has been largely obscured by the massive tephra deposition of 1290 CE. Any paleoclimatic reconstruction based on the study of the diatom and bulk organic matter records in Lake Azul would therefore be largely biased by the overprinting of the volcanic signature after the cataclysmic eruptive episode of 1290 CE, so using alternative proxy data should consequently be preferred instead.

\section{Conclusions}

Artificial fertilization and, secondarily, fish stockings and connectivity with Lake Verde, were the main factors responsible of changes in trophic status in Lake Azul. A vast eruptive episode which implied the deposition of several meters of tephra in the lake ca. 1290 CE determined a state of oligotrophic inertia during approx. $650 \mathrm{yr}$. Since this event the lake experienced a net long-term increase in productivity, but showed a high resilience to change from an oligotrophic to a mesotrophic condition, the latter only being achieved when artificial fertilization and livestock manure practices were intensively implemented in the island in the period 1940-1995 CE. Bottom-up and top-down food web controls by fish stocking in this formerly fishless lake, which started in the $18^{\text {th }}$ century, or nutrient injection 
from Lake Verde overflow in the late $19^{\text {th }}$ century, had a secondary role in lake's trophism. Compared to the mesotrophic Lake Fogo and the eutrophic Lake Furnas, Lake Azul did not significantly change its trophic condition, confirming that the volcanic-induced oligotrophy of the lake, and not trophic interactions, was the main factor explaining the trophic status of the lake during most of its recent history. Other processes, such as natural morphometric eutrophy, or increased delivery of nutrients due to man-induced deforestation and climate variability had a negligible role in reverting the oligotrophic inertia of the lake. By contrast, despite several interventions to avoid the excess nutrient load which drove recent eutrophication, more persistent water stratification seem to maintain or even exacerbate the effects of eutrophication. Lake Azul constitutes an uncommon case in the literature of complete ecosystem restructuring and long-term resilience to trophic change induced by a catastrophic volcanic eruption.

\section{Acknowledgments}

This research was funded by the Ministry of Economy and Competitiveness projects PaleoNAO, RapidNAO and PaleoModes (CGL2010-15767, CGL2013-40608-R and CGL2016-75281-C2, respectively) and by the Fundação para a Ciência e a Tecnologia (PTDC/CTA-AMB/28511/2017). David Vázquez-Loureiro, Armand Hernández, María Jesús Rubio and Pedro Raposeiro benefited with grants from the Xunta de Galicia (I2C Programme co-funded with the European Social Fund), Generalitat de Catalunya (Beatriu de Pinós - Marie Curie cofund programme), Ministry of Economy and Competitiveness (Programa de Formación de Personal Investigador, FPI), and Fundação para a Ciência e

a Tecnologia (SFRH/BPD/99461/2014), respectively. We thank Olga Margalef and Guiomar Sánchez-López for field assistance. Thanks are also extended to two anonymous reviewers for their very useful comments on earlier versions of this manuscript. 


\section{References}

Andrade, J. (2003). Concelho de Ponta Delgada: 500 anos de história : cronologia de figuras e factos, 14991999. [Ponta Delgada, Azores]: Câmara Municipal, 648 pp.

Andrade, C., Trigo, R.M., Freitas, M.C., Gallego, M.C., Borges, P., Ramos, A.M., 2008. Comparing historic records of storm frequency and the North Atlantic Oscillation (NAO) chronology for the Azores region. Holocene 18, 745-754.

Bao, R., Hernández, A., Sáez, A., Giralt, S., Prego, R., Pueyo, J.J., Moreno, A., Valero-Garcés, B.L., 2015. Climatic and lacustrine morphometric controls of diatom paleoproductivity in a tropical Andean lake. Quaternary Sci.Rev. 129, 96-110. https://doi.org/10.1016/j.quascirev.2015.09.019

Barker, P., Telford, R., Merdaci, O., Williamson, D., Taieb, M., Vincens, A., Gibert, E., 2000. The sensitivity of a Tanzanian crater lake to catastrophic tephra input and four millennia of climate change. Holocene 10(3), 303-310. https://doi.org/10.1191/095968300672848582

Barrois, T., 1896. Recherches sur la faune des eaux douce des Açores. Mémoires de la Société des Sciences de l'Agriculture et des Artes de Lille, Série V, Fasc. 6. Société des Sciences de l'Agriculture et des Artes de Lille, Paris.

Bennett, K.D., 1996. Determination of the number of zones in a biostratigraphical sequence. New Phytol. 132, 155-170. https://doi.org/10.1111/j.1469-8137.1996.tb04521.x

Bennett, K.D., 2002. Documentation for Psimpoll 4.10 and Pscomb 1.03, C Programs for Plotting Pollen Diagrams and Analising Pollen Data. Uppsala University.

Bohlin, K., 1901. Étude sur la flore algologique d'eau douce des Açores. Bihang till Kongl. Svenska Vetenskaps-Akademiens 27, 1-85.

Buchaca, T., Skov, T., Amsinck, S., Gonçalves, V., Azevedo, J., Andersen, T., Jeppesen, E., 2011. Rapid Ecological Shift following Piscivorous fish Introduction to increasingly Eutrophic and Warmer Lake Furnas (Azores Archipelago, Portugal): A Paleoecological Approach. Ecosystems 1-20. https://doi.org/10.1007/s10021-011-9423-0

Cañellas-Boltá, N., Rull, V., Sáez, A., Margalef, O., Bao, R., Pla-Rabes, S., Blaauw, M., Valero-Garcés, B., Giralt, S., 2013. Vegetation changes and human settlement of Easter Island during the last millennia: a multiproxy study of the Lake Raraku sediments. Quaternary Sci. Rev. 72, 36-48. https://doi.org/10.1016/j.quascirev.2013.04.004

Catalan, J., Pla-Rabés, S., Wolfe, A., Smol, J., Rühland, K., Anderson, N.J., Kopáček, J., Stuchlík, E., Schmidt, R., Koinig, K., Camarero, L., Flower, R., Heiri, O., Kamenik, C., Korhola, A., Leavitt, P., 
Psenner, R., Renberg, I., 2013. Global change revealed by palaeolimnological records from remote lakes: a review. J.Palelimnol. 49, 513-535. https://doi.org/10.1007/s10933-013-9681-2

Cattaneo, A., Kalff J., 1980. The relative contribution of aquatic macrophytes and their epiphytes to the production of macrophyte beds. Limnol. Oceanogr. 25(2), 280-289.

https://doi.org/10.4319/lo.1980.25.2.0280

Cohen, A.S., 2003. Paleolimnology. Oxford University Press, Oxford.

Cole, P.D., Pacheco, J.M., Gunasekera, R., Queiroz, G., Gonçalves, P., Gaspar, J.L., 2008. Contrasting styles of explosive eruption at Sete Cidades, São Miguel, Azores, in the last 5000 years: Hazard implications from modelling. J. Volcanol. Geoth. Res. 178 (3), 574-591. https://doi.org/10.1016/j.jvolgeores.2008.01.008

Connor, S.E., van Leeuwen, J.F.N., Rittenour, T.M., van der Knaap, W.O., Ammann, B., Björck, S., 2012. The ecological impact of oceanic island colonization-a palaeoecological perspective from the Azores. J. Biogeogr. 39, 1007-1023. https://doi.org/10.1111/j.1365-2699.2011.02671.x

Cropper, T.E., Hanna, E., 2014. An analysis of the climate of Macaronesia, 1865-2012. Int. J. Climatol. 34, 604-622. https://doi.org/10.1002/joc.3710

Cruces, F., Urrutia, R., Parra, O., Araneda, A., Treutler, H., Bertrand, S., Fagel, N., Torres, L., Barra, R., Chirinos, L., 2006. Changes in diatom assemblages in an Andean lake in response to a recent volcanic event. Arch. für Hydrobiol. 165, 23-35.

Cruz, J.V, Antunes, P., Amaral, C., França, Z., Nunes, J.C., 2006. Volcanic lakes of the Azores archipelago (Portugal): Geological setting and geochemical characterization. J. Volcanol. Geotherm. Res. 156, 135157.

Cruz, J.V., Pacheco, D., Porteiro, J., Cymbron, R., Mendes, S., Malcata, A., Andrade, C., 2015. Sete Cidades and Furnas lake eutrophication (São Miguel, Azores): Analysis of long-term monitoring data and remediation measures. Sci. Total Environ. 520, 168-186.

https://doi.org/10.1016/j.scitotenv.2015.03.052

Cunha, A. G. 1939. Sur la flore charologique des iles Açoréennes. Bulletin de la Société Portugaise des Sciences Naturelles , 13 (13): 67-70

Dias, E., 1996. Vegetação natural dos Açores: ecologia e sintaxonomia das florestas naturais. PhD Thesis. Universidade dos Açores, Angra do Heroismo.

Egan, J., Allott, T.E.H., Blackford, J.J., 2019. Diatom-inferred aquatic impacts of the mid-Holocene eruption of Mount Mazama, Oregon, USA. Quat. Res. 91, 163-178. https://doi.org/10.1017/qua.2018.73 
Ellis, B.K., Stanford, J.A., Goodman, D., Stafford, C.P., Gustafson, D.L., Beauchamp, D.A., Chess, D.W., Craft, J.A., Deleray, M.A., Hansen, B.S., 2011. Long-term effects of a trophic cascade in a large lake ecosystem. Proc. Natl. Acad. Sci., 108: 1070-1075. https://doi.org/10.1073/pnas.1013006108

Elser, J.J., Andersen, T., Baron, J.S., Bergstrom, A.-K., Jansson, M., Kyle, M., Nydick, K.R., Steger, L., Hessen, D.O., 2009. Shifts in Lake N:P Stoichiometry and Nutrient Limitation Driven by Atmospheric Nitrogen Deposition. Science 326, 835-837. https://doi.org/10.1126/science.1176199

Elser, J.J., Goldman, C.R., 1991. Zooplankton effects on phytoplankton in lakes of contrasting trophic status. Limnol. Oceanogr. 36, 64-90. https://doi.org/10.4319/lo.1991.36.1.0064

Fee, E.J., 1979. A relation between lake morphometry and primary productivity and its use in interpreting whole-lake eutrophication experiments. Limnol. Oceanogr. 24(3), 401-416. http://dx.doi.org/10.4319/lo.1979.24.3.0401

Flor de Lima, H.M.Q., 1993. Contribuição para o estudo ictiológico das lagoas das Furnas e Sete Cidades. Estudos, Experimentação e Divulgação. p. 99., Ponta Delgada.

France, R.L., 1995. Differentiation between littoral and pelagic food webs in lakes using stable carbon isotopes. Limnol. Oceanogr. 40, 1310-1313. https://doi.org/10.4319/lo.1995.40.7.131

Frutuoso, G., 1977.Livro Quarto das Saudades da Terra. Instituto Cultural de PontaDelgada, Ponta Delgada, $1593 \mathrm{pp}$.

Gawel, J.E., Crisafulli, C.M., Miller, R., 2018. The New Spirit Lake: Changes to Hydrology, Nutrient Cycling, and Biological Productivity, in: Crisafulli, C.M., Dale, V.H. (Eds.), Ecological Responses at Mount St. Helens: Revisited 35 Years after the 1980 Eruption. Springer New York, New York, NY, pp. 71-95. https://doi.org/10.1007/978-1-4939-7451-1_4

Gonçalves, V., 2008. Contribuçao para o estudo da qualidade ecológica das lagoas dos Açores. Fitoplâncton e diatomáceas bentónicas. PhD. Dissertation, Universidade dos Açores, Ponta Delgada, $343 \mathrm{pp}$.

Gonçalves, V., Marques, H., Fonseca, A., 2010. Lista das Diatomáceas (Bacillariophyta), in: Borges, P.A.V., Bried, J., Costa, A., Cunha, R., Gabriel, R., Gonçalves, V., Martins, A.F., Melo, I., Parente, M., Raposeiro, P., Rodrigues, P., Santos, R.S., Silva, L., Vieira, P., Vieira, V. (Eds.), Listagem dos Organismos Terrestres e Marinhos dos Açores. Princípia, Cascais, pp. 81-97.

Gonçalves V., Costa A.C., Raposeiro P.M., Marques H.S., Cunha A., Ramos J., Cruz A.M., Pereira C.L., Vilaverde J., 2013. Monitorização das Massas de Água Interiores da Região Hidrográfica Açores. Relatório Anual de 2012 (R5/2012). CIBIO Açores, Departamento de Biologia, Universidade dos 
Açores, Ponta Delgada, 261 pp.

Grimm, E.C., 1987. CONISS: a Fortran 77 program for stratigraphically constrained cluster analysis by the method of incremental sum of squares. Comput. Geosci. 13, 13-35. https://doi.org/10.1016/00983004(87)90022-7

Hall, R.I., Smol, J.P., 2010. Diatoms as indicators of lake eutrophication, in: Smol, J.P., Stoermer, E.F. (Eds.), The Diatoms: Applications for the Environmental and Earth Sciences. Cambridge University Press, Cambridge, pp. 122-151.

Harper, M.A., Howorth, R., McLeod, M., 1986. Late Holocene diatoms in Lake Poukawa: Effects of airfall tephra and changes in depth. New Zeal. J. Mar. Fres. 20(1), 107-118. httpS://doi.org/10.1080/00288330.1986.9516135

Hansson, L. A., 1992. Factors regulating periphytic algal biomass. Limnol. Oceanogr. 37(2), 322-328. https://doi.org/10.4319/lo.1992.37.2.0322

Hernández, A., Kutiel, H., Trigo, R.M., Valente, M.A., Sigró, J., Cropper, T., Santo, F.E., 2016. New Azores archipelago daily precipitation dataset and its links with large-scale modes of climate variability. Int. J. Climatol. 36, 4439-4454. https://doi.org/10.1002/joc.4642

Hernández, A., Sáez, A., Bao, R., Raposeiro, P.M., Trigo, R.M., Doolittle, S., Masqué, P., Rull, V., Gonçalves, V., Vázquez-Loureiro, D., Rubio-Inglés, M.J., Sánchez-López, G., Giralt, S., 2017. The influences of the AMO and NAO on the sedimentary infill in an Azores Archipelago lake since ca. 1350 CE. Global Planet. Change 154, 61-74. https://doi.org/10.1016/j.gloplacha.2017.05.007

Hobbs, W.O., Fritz, S.C., Stone, J.R., Donovan, J.J., Grimm, E.C., Almendinger, J.E., 2011. Environmental history of a closed-basin lake in the US Great Plains: Diatom response to variations in groundwater flow regimes over the last 8500 cal. yr BP. Holocene 21, 1203-1216.

https://doi.org/10.1177/0959683611405242

Hughes, S.J., Malmqvist, B., 2005. Atlantic Island freshwater ecosystems: challenges and considerations following the EU Water Framework Directive. Hydrobiologia 544, 289-297. https://doi.org/10.1007/s10750-005-1695-y

Jeppesen, E., Meerhoff, M., Davidson, T., Trolle, D., Søndergaard, M., Lauridsen, T., Beklioglu, M., Brucet, S., Volta, P., González-Bergonzoni, I., Nielsen, A., 2014. Climate change impacts on lakes: An integrated ecological perspective based on a multi-faceted approach, with special focus on shallow lakes. J. Limnol. 73, 88-111. https://doi.org/10.4081/jlimnol.2014.844

Kilham P., Kilham S.S., Hecky R.E., 1986. Hypothesized resource relationships among African planktonic 
diatoms. Limnol. Oceanogr. 6, 1169-1181. https://doi.org/ 10.4319/lo.1986.31.6.1169

Kingsbury, M.V, Laird, K.R., Cumming, B.F., 2012. Consistent patterns in diatom assemblages and diversity measures across water-depth gradients from eight Boreal lakes from North-Western Ontario (Canada). Freshw. Biol. 57, 1151-1165. https://doi.org/10.1111/j.1365-2427.2012.02781.x

Kohler, A., Labus, B.C., 1983. Eutrophication processes and pollution of freshwater ecosystems including waste heat, in: Lange, O.L., Nobel, P.S., Osmond, C.B., Ziegler, H. (Eds.), Physiological Plant Ecology IV. Ecosystem Processes: Mineral Cycling, Productivity and Man's Influence. Springer, Berlin, pp. 413-464.

Krammer, K., Lange-Bertalot, H., 1986-1991. Bacillariophyceae. Volumes 1-4, in: Ettl, H., Gerloff, J., Heynig, H., Mollenhauer, D. (Eds.), Süßwasserflora von Mitteleuropa. Fischer-Verlag, Stuttgart. Lange-Bertalot, H., 2000-2013. Diatoms of the European Inland Waters and Comparable Habitats. In: Volumes 1-7. A. R. G. Gantner Verlag, Ruggell, Liechtenstein, A. R. G.

Larson, D.W., Sweet, J., Petersen, R.R., Crisafulli, C.M., 2006. Posteruption Response of Phytoplankton and Zooplankton Communities in Spirit Lake, Mount St. Helens, Washington. Lake Reserv. Manag. 22, 273292. https://doi.org/10.1080/07438140609354362

Le Moal, M., Gascuel-Odoux, C., Ménesguen, A., Souchon, Y., Étrillard, C., Levain, A., Moatar, F., Pannard, A., Souchu, P., Lefebvre, A., Pinay, G., 2019. Eutrophication: A new wine in an old bottle?. Sci. Total Environ. 651, 1-11. https://doi.org/10.1016/j.scitotenv.2018.09.139

Lees, K., Pitois, S., Scott, C., Frid, C., Mackinson, S., 2006. Characterizing regime shifts in the marine environment. Fish Fish. 7, 104-127. https://doi.org/10.1111/j.1467-2979.2006.00215.x

Leira, M., Filippi, M.L., Cantonati, M., 2015. Diatom community response to extreme water-level fluctuations in two Alpine lakes: a core case study. J. Paleolimnol. 53, 289-307. https://doi.org/10.1007/s10933015-9825-7

Leps, J., Smilauer, P., 2003. Multivariate Analysis of Ecological Data Using CANOCO. Cambridge University Press, Cambridge, 268 pp.

Lotter, A.F., Birks, H.J.B., Zolitschka, B., 1995. Late-glacial pollen and diatom changes in response to two different environmental perturbations: volcanic eruption and Younger Dryas cooling. J. Paleolimnol. 14, $23-47$.

Mantzouki, E., Lürling, M., Fastner, J., de Senerpont Domis, L., Wilk-Woźniak, E., et al., 2018. Temperature Effects Explain Continental Scale Distribution of Cyanobacterial Toxins. Toxins (Basel). 10, e156.

Margalef, R., 1978. Life forms of phytoplankton as survival alternatives in an unstable environment. Oceanol. Acta 1(4), 493-509. 
McQueen, D.J., Johannes, M.R.S., Post, J.R., Stewart, T.J., Lean, D.R.S., 1989. Bottom-up and top-down impacts on freshwater pelagic community structure. Ecol. Monogr. 59, 289-309.

https://doi.org/10.2307/1942603

Meyers, P.A., Teranes, J.L., 2001. Sediment organic matter, in: Smol, J.P., Birks, H.J.B., Last, W.M. (Eds.), Tracking Environmental Change Using Lake Sediments, vol. 2: Physical and Geochemical Methods. Kluwer Academic Publishers, Dordrecht, pp. 239-269.

Modenutti, B.E., Balseiro, E.G., Elser, J.J., Navarro, M.B., Cuassolo, F., Laspoumaderes, C., Souza, M.S., Villanueva, V.D., 2013. Effect of volcanic eruption on nutrients, light, and phytoplankton in oligotrophic lakes. Limnol. Oceanogr. 58, 1165-1175. https://doi.org/10.4319/lo.2013.58.4.1165

Pereira, C.L., Raposeiro, P.M., Costa, A.C., Bao, R., Giralt, S., Gonçalves, V., 2014. Biogeography and lake morphometry drive diatom and chironomid assemblages' composition in lacustrine surface sediments of oceanic islands. Hydrobiologia 730, 93-112. https://doi.org/10.1007/s10750-014-1824-6

Peterson, C., Stevenson, R., 1992. Resistance and resilience of lotic algal communities: Importance of disturbance timing and current. Ecology 73(4), 1445-1461. https://doi.org/10.2307/1940689

Potapova, M., Hamilton, P.B., 2007. Morphological and ecological variation within the Achnanthidium minutissimum (Bacillariophyceae) species complex. J. Phycol. 43, 561-575.

Queiroz, G. 1997. Vulcao das Sete Cidades (S. Miguel, Açores). Historia eruptiva e Avaliaçao do Hazrd. PhD Thesis. Azores University, 226 pp.

Queiroz, G., Pacheco, J.M., Gaspar, J.L., Aspinall, W.P., Guest, J.E., Ferreira, T., 2008. The last 5000 years of activity at Sete Cidades volcano (São Miguel Island, Azores): implications for hazard assessment. J. Volcanol. Geoth. Res. 178: 562-573. https://doi.org/10.1016/j.jvolgeores.2008.03.001

Raposeiro, P.M., Rubio, M.J., González, A., Hernández, A., Sánchez-López, G., Vázquez-Loureiro, D., Rull, V., Bao, R., Costa, A.C., Gonçalves, V., Sáez, A., Giralt, S., 2017. Impact of the historical introduction of exotic fishes on the chironomid community of Lake Azul (Azores Islands). Palaeogeogr. Palaeocl. 466, 77-88. https://doi.org/10.1016/j.palaeo.2016.11.015

Rawson, D.S., 1955. Morphometry as a dominant factor in the productivity of large lakes. Int. Vereinigung fuer Theor. und Angew. Limnol. Verhandlungen 12, 164-175.

Reclus, E., 1830-1905. Africa and its inhabitants. In: Volume 2. Virtue, London, J. S.

Reed, J., Roberts, N., Leng, M., 1999. An evaluation of the diatom response to Late Quaternary environmental change in two lakes in the Konya Basin, Turkey, by comparison with stable isotope data. Quat. Sci. Rev. 18, 631-646. https://doi.org/10.1016/S0277-3791(98)00101-2 
Reimer, P.J., Bard, E., Bayliss, A., Beck, J.W., Blackwell, P.G., Ramsey, C.B., Buck, C.E., Cheng, H., Edwards, R.L., Friedrich, M., Grootes, P.M., Guilderson, T.P., Haflidason, H., Hajdas, I., Hatté, C., Heaton, T.J., Hoffmann, D.L., Hogg, A.G., Hughen, K.A., Kaiser, K.F., Kromer, B., Manning, S.W., Niu, M., Reimer, R.W., Richards, D.A., Scott, E.M., Southon, J.R., Staff, R.A., Turney, C.S.M., van der Plicht, J., 2013. IntCal13 and Marine13 Radiocarbon Age Calibration Curves 0-50,000 years cal BP. Radiocarbon 55, 1869-1887. https://doi.org/10.2458/azu_js_rc.55.16947

Renberg, I., 1990. A procedure for preparing large sets of diatom slides from sediment cores. J. Paleolimnol. 4, 87-90. https://doi.org/10.1007/BF00208301

Reynolds, C.S., 2006. The Ecology of Phytoplankton. Cambridge University Press, Cambridge.

Reynolds, C.S., Huszar, V., Kruk, C., Naselli-Flores, L., Melo, S., 2002. Towards a functional classification of the freshwater phytoplankton. J. Plankton Res. 24, 417-428. https://doi.org/10.1093/plankt/24.5.417

Richardson, M.J., Whoriskey, F.G., Roy, L.H., 1995. Turbidity generation and biological impacts of an exotic fish Carassius auratus, introduced into shallow seasonally anoxic ponds. J. Fish Biol. 47:576-585. https://doi.org/10.1111/j.1095-8649.1995.tb01924.x

Robinson, M., 2004. A late glacial and Holocene diatom record from Clettnadal, Shetland Islands, northern Scotland. J. Paleolimnol.31, 295-319. https://doi.org/10.1023/B:JOPL.0000021716.49552.da

Rühland, K., Paterson, A.M., Smol, J.P., 2008. Hemispheric-scale patterns of climate-related shifts in planktonic diatoms from North American and European lakes. Glob. Change Biol. 14, 2740-2754. https://doi.org/10.1111/j.1365-2486.2008.01670.x

Rull, V., Lara, A., Rubio-Inglés, M.J., Giralt, S., Gonçalves, V., Raposeiro, P., Hernández, A., SánchezLópez, G., Vázquez-Loureiro, D., Bao, R., Masqué, P., Sáez, A., 2017. Vegetation and landscape dynamics under natural and anthropogenic forcing on the Azores Islands: a 700-year pollen record from the São Miguel Island. Quat. Sci. Rev. 159, 155-168. https://doi.org/10.1016/j.quascirev.2017.01.021

Santos, F.D., Valente, M.A., Miranda, P.M.A., Aguiar, A., Azevedo, E.B., Tome, A.R., Coelho, F., 2004. Climate change scenarios in the Azores and Madeira Islands. World Resour. Rev. 16, 473-491.

Saros, J.E., Anderson, N.J., 2015. The ecology of the planktonic diatom Cyclotella and its implications for global environmental change studies. Biol. Rev. 90, 522-541. https://doi.org/10.1111/brv.12120

Saros, J.E., Michel, T.J., Interlandi, S.J., Wolfe, A.P., 2005. Resource requirements of Asterionella formosa and Fragilaria crotonensis in oligotrophic alpine lakes: implications for recent phytoplankton community reorganizations. Can. J. . Fish. Aquat. Sci. 62, 1681-1689. https://doi.org/10.1139/f05-077 
Sax, D.F., Gaines, S.D., 2008. Species invasions and extinction: the future of native biodiversity on islands. Proc. Natl. Acad. Sci. 105, 11490-11497. https://doi.org/10.1073/pnas.0802290105

Scheffer, M., van Nes, E., 2007. Shallow lakes theory revisited: various alternative regimes driven by climate, nutrients, depth and lake size. Hydrobiologia 584, 455-466. https://doi.org/10.1007/s10750-007-06167

Schindler, E.D., Knapp, A.R., Leavitt, R.P., 2001. Alteration of nutrient cycles and algal production resulting from fish introductions into mountain lakes. Ecosystems 4, 308-321. https://doi.org/10.1007/s10021001-0013-4

Shotton, F.W., Williams,R.E.G., 1971. Birmingham University Radiocarbon dates V. Radiocarbon 11, 141156. https://doi.org/10.1017/S0033822200008419

Skov, T., Buchaca, T., Amsinck, S., Landkildehus, F., Odgaard, B., Azevedo, J., Gonçalves, V., Raposeiro, P., Andersen, T., Jeppesen, E., 2010. Using invertebrate remains and pigments in the sediment to infer changes in trophic structure after fish introduction in Lake Fogo: a crater lake in the Azores.

Hydrobiologia 654, 13-25. https://doi.org/10.1007/s10750-010-0325-5

Smith, V.H., 2003. Eutrophication of freshwater and coastal marine ecosystems a global problem. Environ. Sci. Pollut. Res. 10, 126-139. https://doi.org/10.1065/espr2002.12.142.

Stenger-Kovács, C., Padisák, J., Bíró, P., 2006. Temporal variability of Achnanthidium minutissimum (Kützing) Czarnecki and its relationships to chemical and hydrological features of the Torna-stream, Hungary. Program, abstracts \& extended abstracts: 6th International Symposium on Use of Algae for monitoring Rivers. Magyar Algológiai Társaság, Göd, pp. 133-138. ISBN 9630604973

Stevenson, R.J., Bothwell, M.L., Lowe, R.L., 1996. Algal Ecology. Academic Press, San Diego, pp. 759.

Stone, J.R., Fritz, S.C., 2004. Three-dimensional modeling of lacustrine diatom habitat areas: improving paleolimnological interpretation of planktic : benthic ratios. Limnol. Oceanogr. 49, 1540-1548. https://doi.org/10.1371/journal.pone.0108936

Stuiver, M., Reimer, P.J., 1993. Extended ${ }^{14} \mathrm{C}$ data base and revised CALIB $3.014 \mathrm{C}$ age calibration program. Radiocarbon 35, 215-230. https://doi.org/10.1017/S0033822200013904

Talbot, M.R., 2001. Nitrogen isotopes in paleolimnology, in: Smol, J.P., Birks, H.J.B., Last, W.M. (Eds.), Tracking Environmental Change Using Lake Sediments. Physical and Geochemical Methods, vol. 2. Kluwer Academic Publishers, Dordrecht, pp. 401-439.

Telford, R.J., Barker, P., Metcalfe, S.E., Newton, A., 2004. Lacustrine responses to tephra deposition: examples from Mexico. Quat. Sci. Rev. 23, 2337-2353. https://doi.org/10.1016/j.quascirev.2004.03.014 
ter Braak, C.J.F., Smilauer, P., 1998. CANOCO Reference Manual and User's Guide to CANOCO for Windows: Software for Canonical Community Ordination (Version 4). Microcomputer Power, Ithaca, New York.

Thornton, J.A., Harding, W.R., Dent, M., Hart, R.C., Lin, H., Rast, C.L., Rast, W., Ryding, S.-O., Slawski, T.M., 2013. Eutrophication as a ‘wicked’ problem. Lakes Reserv. Sci. Policy Manag. Sustain. Use 18, 298-316. https://doi.org/10.1111//re.12044

Trelease, W., 1897. Botanical Observations on the Azores. Missouri Bot. Gard. Annu. Rep. 1897, 77-220. https://doi.org/10.2307/2992160

Valois-Silva, F., 1886. Descrição das águas minerais das Furnas na ilha de São Miguel, Archivo dos Açores. Vol. 8. Typografia do archivo dos Açores. (Ponta Delgada). pp. 437-446.

Van Eaton, A.R., Harper, M.A., Wilson, C.J.N., 2013. High-flying diatoms: Widespread dispersal of microorganisms in an explosive volcanic eruption. Geology 41, 1187-1190. https://doi.org/10.1130/G34829.1

Vanni, M., 2002. Nutrient cycling by animals in freshwater ecosystems. Annu. Rev. Ecol. Syst. 33, 341-370. https://doi.org/10.1146/annurev.ecolsys.33.010802.150519

Vicente, A., 1956. Introdução de peixes de água doce nas lagoas de S. Miguel. Açoreana 5.

Vidal, A.T.E., Hidrographic Office, R.U., Walker, J.\& C.C.N.-C.C. 166 A.. C.C. 166 A., 1850. San Miguel. Hydrographic Office, London.

Volkov, D.L., Fu, L.-L., 2010. On the reasons for the formation and variability of the Azores current. J. Phys. Oceanogr. 40, 2197-2220. https://doi.org/10.1175/2010JPO4326.1

Wang, Q., Yang, X., Hamilton, P., Zhang, E., 2012. Linking spatial distributions of sediment diatom assemblages with hydrological depth profiles in a plateau deep-water lake system of subtropical China. Fottea 12, 59-73. https://doi.org/ 10.5507/fot.2012.005

Werner, D., 1977. The Biology of Diatoms. University of California Press, Berkely and Los Angeles, 498 pp. Wigdahl, C.R., Saros, J.E., Fritz, S.C., Stone, J.R., Engstrom, D.R., 2014. The influence of basin morphometry on the regional coherence of patterns of diatom-inferred salinity in lakes of the northern Great Plains (USA). Holocene 24, 603-613. https://doi.org/10.1177/0959683614523154

Wolin, J.A., Stone, J.R., 2010. Diatoms as indicators of water-level change in freshwater lakes. In: Smol, J.P., Stoermer, E.F. (Eds.), The Diatoms: Applications for the Environmental and Earth Sciences. Cambridge University Press, Cambridge, pp. 174-185.

Wood, J.R., Alcover, J.A., Blackburn, T.I.M.M., Bover, P., Duncan, R.P., Hume, J.P., Louys, J., Meijer, 
H.J.M., Rando, J.C., Wilmhurst, J.M., 2017. Island extinctions: processes, patterns, and potential for ecosystem restoration. Environ. Conserv. 44, 348-358. https://doi.org/10.1017/S037689291700039X Yamamoto, A., Palter, J.B., 2016. The absence of an Atlantic imprint on the multidecadal variability of wintertime European temperature. Nat. Commun. 7. https://doi.org/10.1038/ncomms 10930 


\section{Table captions}

Table 1. Environmental variables of Lake Azul and Verde, obtained from Pereira et al. (2014) and Gonçalves (2008).

Table 2. Radiocarbon and calibrated dates from AZ11 core samples. (*) Used in the construction of the age model (see explanation in the text).

Table 3. Summarized description of diatom assemblage zones from Lake Azul.

\section{Figure captions}

Figure 1. A and B. Location of Azores archipelago and São Miguel island. C. Location of Sete Cidades crater caldera on São Miguel island with lakes Azul (rectangle) and Verde on caldera floor. D. Bathymetric map of Lake Azul showing transects A and $B$ and cores recovered. Coring sites studied in this work (AZ06 and AZ11) are indicated with red circles.

Figure 2. NE-SW cross section of Lake Azul showing lithological units, coring sites, and main sedimentary subenvironments. Thickness of lacustrine units not to scale.

Figure 3. Updated age-depth model (black line) based on the ${ }^{210} \mathrm{~Pb}$ activity-depth profile of core AZ06 (Gonçalves, 2008) and the AMS ${ }^{14} \mathrm{C}$ dates of core AZ11-02. The expected age was calculated using linear interpolation and compared with palynological data studied in the same core (Rull et al., 2017). Plot of the previous age model (gray line) for core AZ11-02 (Raposeiro et al., 2017; Rull et al., 2017) is also shown for comparison purposes. Corresponding sedimentary units are indicated. 
Figure 4. Diatom percentage diagram for selected taxa ( $\geq 5 \%$ abundance in at least one sample) of Lake Azul cores: AZ11-02 (filled curves) and AZ06 (discontinued lines). Composite column on the left is based on the biostratigraphical correlation of both cores (see text). Notice comparison of the Aulacoseira spp. and Psammothidium abundans f. rosenstockii, among other taxa, percent abundance curves used for stratigraphic correlation of cores AZ11-02 and AZ06. Diatoms are grouped according to their habitat preferences. Diatom Assemblage Zones generated by a broken-stick model of the distribution of variance (Bennett, 1996) are represented by discontinued lines. Main lithological units and sedimentary facies are also shown.

Figure 5. Principal Component Analysis (PCA) ordination biplot of samples (numbers) and diatom taxa (acronyms) in Lake Azul. Achmin=Achnanthidium minutissimum, Adlmin=Adlafia minuscula var. muralis, Astfor=Asterionella formosa, Aulamb=Aulacoseira ambigua, Aulgra=Aulacoseira granulata, Diswol=Discostella woltereckii, Encces=Encyonopsis spp. aff. Cesatii, Eolsp1=Eolimna sp1, Eolsp2=Eolimna sp2, Eunimp=Eunotia implicata, Fracap=Fragilaria capucina, Fracro $=$ Fragilaria crotonensis, Fraten=Fragilaria tenera Navnot=Navicula notha, Nitgra=Nitzschia gracilis, Nitlac=Nitzschia lacuum, Nitper=Nitzschia perminuta, Nitpse=Nitzschia spp. aff. pseudofonticola, Pladau=Planothidium daui, Psaros= Psammnothidium abundans f. rosenstocki, Psebre=Pseudostaurosira brevistriata, Pseell=Pseudostaurosira elliptica, Rospus=Rosithidium pusillum, Stfexi=Stauroforma exiguiformis, Stamut=Staurosira mutabilis, Stapse=Staurosira pseudoconstruens, Tabflo=Tabellaria flocculosa. Shadings correspond to the two main groups of samples reflecting differences in trophic status. 
Figure 6. Geochemical and diatom proxy data for Lake Azul. Proxies include: percent total organic carbon (\%TOC), TOC mass accumulation rates (MARs), percent total nitrogen (\%TN), TOC/TN (black line) and $\mathrm{TOC} / \mathrm{TN}_{\text {corr }}$ (gray line) ratio (following Talbot, 2001), carbon and nitrogen isotopes of organic matter $\left(\delta^{13} \mathrm{Corg}_{\text {, }} \delta^{15} \mathrm{Norg}\right)$, and sample scores for axis 1 (PC1) and axis 2 (PC2) of Principal Component Analysis on the diatom assemblages. All data are plotted against age (cal yr CE).

\section{Supplementary material captions}

Supplementary material I: Diatom abundance data

Supplementary material II: Bulk organic matter elemental and isotopic composition

Supplementary material III: Synthetic correlation diagram of chironomid biozones (core AZ11-02; Raposeiro et al., 2017), pollen zones (core AZ11-02; Rull et al., 2017), and diatom assemblage zones (composite column AZ06+AZ11-02; this work), showing the preliminary and updated age-depth models.

*Supplementary material I and Supplementary material II can be found at https://doi.org/10.1016/i.palaeo.2019.109285. 
Values

Lake Azul Lake Verde

\section{Hydromorphological}

Volume $\left(10^{3} \mathrm{~m}^{3}\right)$

Maximum depth $(\mathrm{m})$

Lake area $\left(\mathrm{km}^{2}\right)$

7696

\section{Physicochemical}

Temperature ( $\left.{ }^{\circ} \mathrm{C}\right)$

July temperature $\left({ }^{\circ} \mathrm{C}\right)$

$\mathrm{pH}$

Conductivity $\left(\mu \mathrm{S} \mathrm{cm}^{-1}\right)$

39764

25.35

23.50

3.59

0.86

Total phosphorous $\left(\mu \mathrm{P} \mathrm{P}^{-1}\right)$

T nitrogen $\left(\mathrm{mg} \mathrm{N} \mathrm{I}^{-1}\right)$

Nitrate $\left(\mathrm{mg} \mathrm{NO}_{3} \mathrm{I}^{-1}\right)$

Silica (mg SiO $\left.\mathrm{I}^{-1}\right)$

Transparency $(\mathrm{m})$

16.48

15.78

Chlorophyll a

18.70

19.20

7.83

8.61

94.55

118.50

\section{Catchment variables}

Agricultural area (\%)

$9.5 \quad 28.5$

Forestal area (\%)

$0.19 \quad 0.43$

$0.03 \quad 0.06$

Other land uses (\%)

0.70

$2.20 \quad 1.25$

$5.35 \quad 26.19$

Table 1: Environmental variables of Lakes Azul and Verde. 


\begin{tabular}{|c|c|c|c|c|c|c|c|}
\hline Core & $\begin{array}{l}\text { Core depth } \\
\qquad(\mathrm{mm})\end{array}$ & $\begin{array}{l}\text { Composite column } \\
\text { depth (mm) }\end{array}$ & Material & Lab. Reference & $\begin{array}{l}\text { Radiocarbon age } \\
\text { (BP) }\end{array}$ & $2 \sigma$ (cal yrs. CE) & $\delta^{13} \mathrm{C}(\%)$ \\
\hline$A Z 11-02$ & 55 & 340 & Plant macrorest & Beta-326594 & $154.4 \pm 0.4 \mathrm{pMC}$ & 1989-1991 & -32.7 \\
\hline AZ11-03 & 650 & 700 & Plant macrorest & Beta-316597 & $120 \pm 30$ & $1801-1939^{*}$ & -24.6 \\
\hline AZ11-02 & 460 & 750 & Plant macrorest & Beta-316595 & $200 \pm 30$ & 1634-1892 & -28.6 \\
\hline AZ11-02 & 610 & 900 & Pollen concentrate & Beta-331408 & $410 \pm 30$ & $1431-1521^{*}$ & -25.8 \\
\hline AZ11-02 & 860 & 1150 & Pollen concentrate & Beta-331409 & $690 \pm 30$ & $1266-1312^{*}$ & -25.3 \\
\hline
\end{tabular}

Table 2: Radiocarbon dates. 


\section{Diatom \\ assemblage}

zone

Depth (cm)

Age (ca. CE)

\section{Main taxa}

AZU-1 Biraphid diatoms, mainly benthic life forms (epipelic), dominated by Eolimna sp1 and subdominated by Navicula 125-90 notha, Encyonopsis spp. aff. cesatii, Nitzschia perminuta, N. lacuum and Nitzchia spp. aff. pseudofonticola. (1290-1475) Aerophilic diatoms reach high abundances coinciding with Facies D, and tychoplanktonic life forms appear sporadically in low values.

Marked increase in periphyton, mainly tychoplanktonic and epiphytic taxa from littoral areas, such as Peudostaurosira brevistriata, Staurosira elliptica, Fragilaria capucina and varieties, Staurosira mutabilis and Tabellaria flocculosa

AZU-2 (morph1). Decline of biraphid forms, except for E. aff. cesatii. Low abundances of Rosithidium pusillum and

$90-41$ (1475-1930) Stauroforma exiguiformis. Aerophilic taxa reach high abundances coinciding with Facies D (subzone AZU-2b). The euplanktonic Aulacoseira appears for the first time in the record, initially associated to this facies and with episodic peaks and uninterrupted low abundances thereafter, accompanied by epiphytic Psammnothidium abundans $\mathrm{f}$. rosenstockii and benthic Eolimna sp2.

\section{AZU-3}

$41-11$ (1930-1985)

Sharp increase of the euplanktonic and eutrophic Aulacoseira ambigua, which dominates the assemblage, and $A$. granulata. Both taxa decline in the topmost levels. The tychoplanktonic $P$. brevistriata and $S$. elliptica are subdominant taxa.

\section{AZU-4}

$11-0$ (1985-2006)

Partial replacement of Aulacoseira spp. with other euplanktonic diatoms, mainly Asterionella formosa and Fragilaria crotonensis.

\section{Table 3: Description of Diatom Assemblage Zones.}



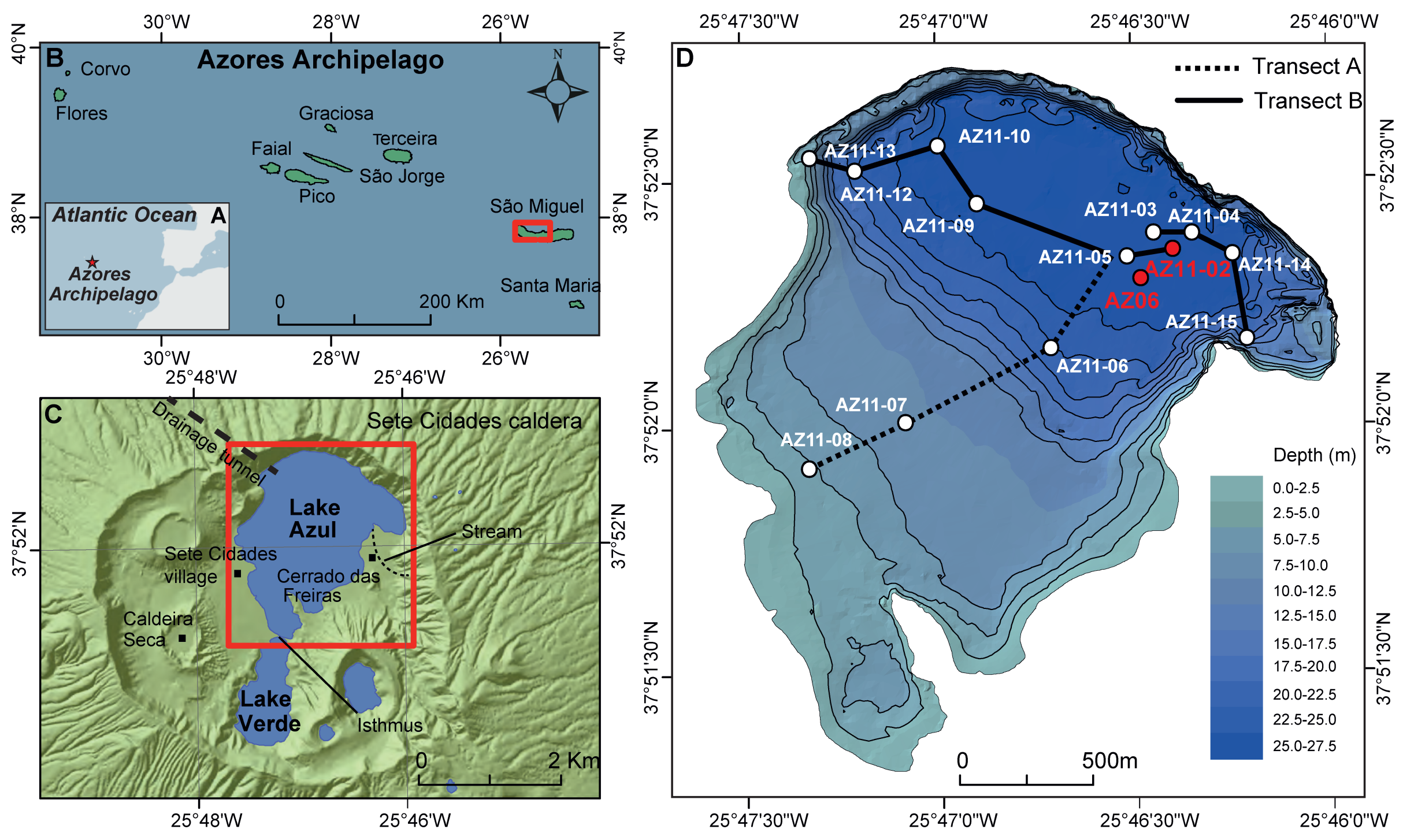

Figure 1 


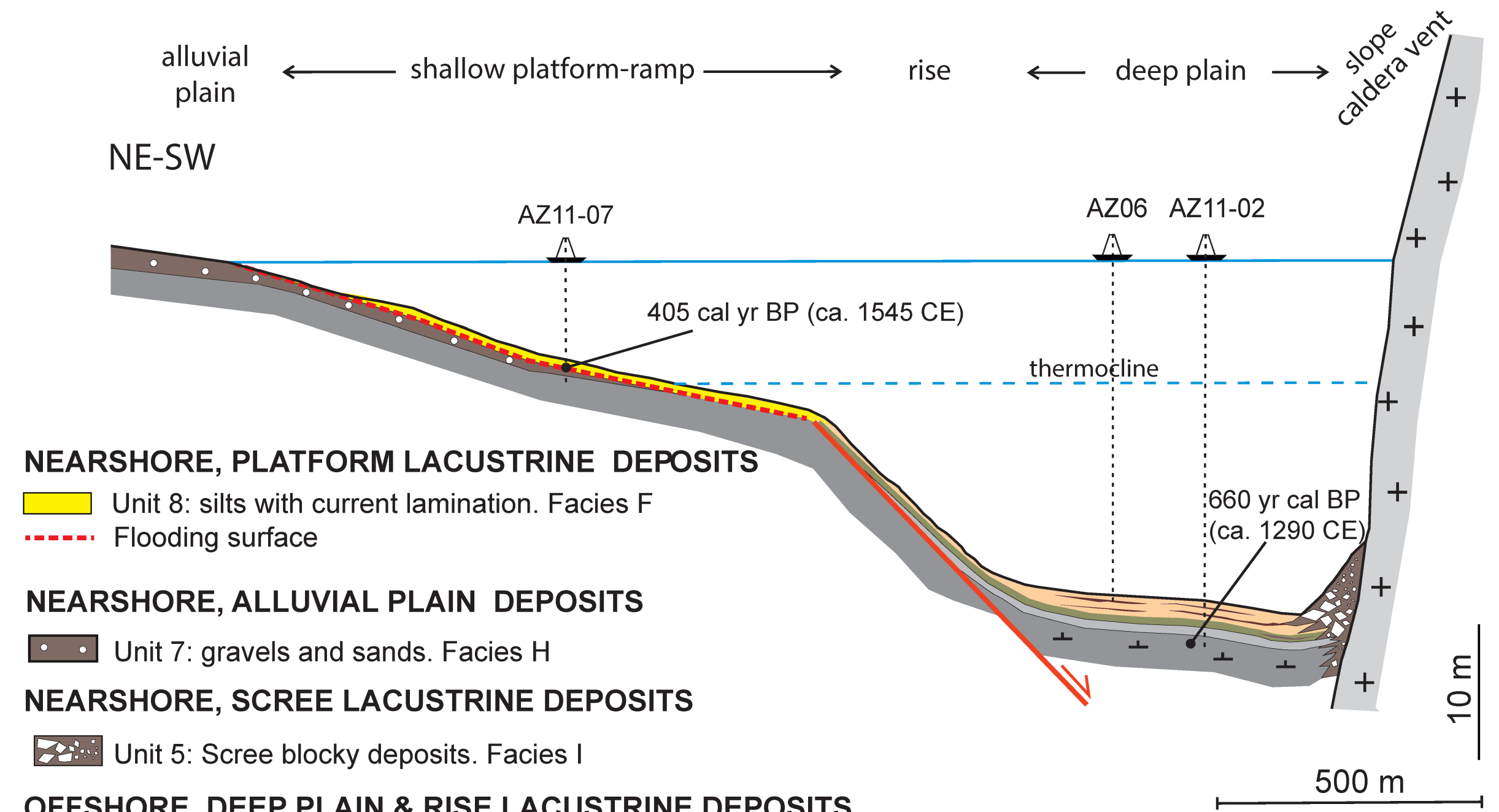

\section{OFFSHORE, DEEP PLAIN \& RISE LACUSTRINE DEPOSITS}

- Units 3 and 4: terrestrial plant rich lobe (flood event). Facies D

\section{VOLCANIC ROCKS}

Unit 4: brown massive mud (Facies $A$ ), interbedding layers enriches in shards (Facies B)

Unit 3: greenish/yellowish laminated mud. Facies C

Unit 1: ash and lapilli (Facies VS) interbedding thin lacustrine layers

+ Volcanic bedrock

Unit 2: grey laminated mud. Facies $E$

\section{Figure 2}




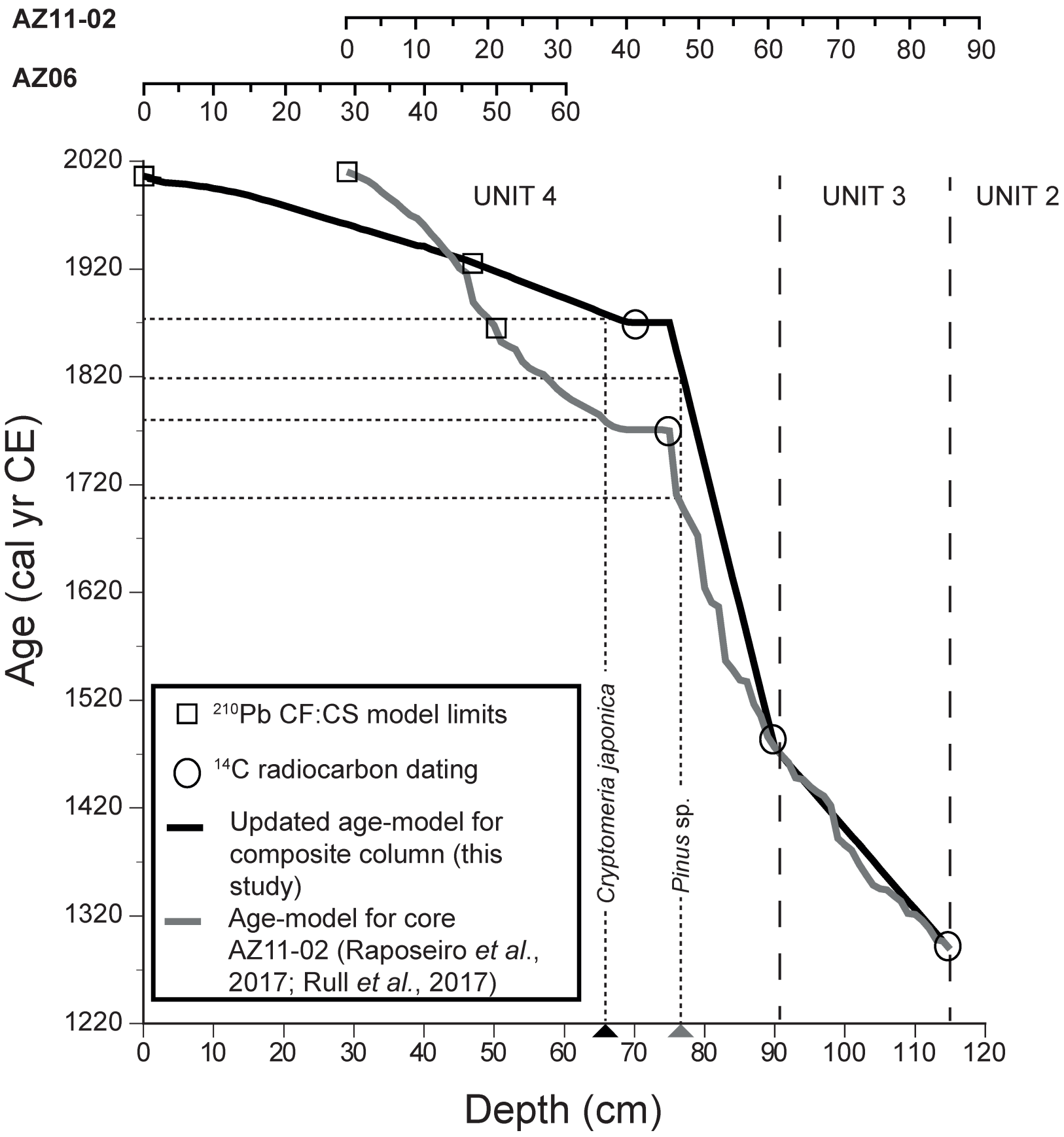

Figure 3 


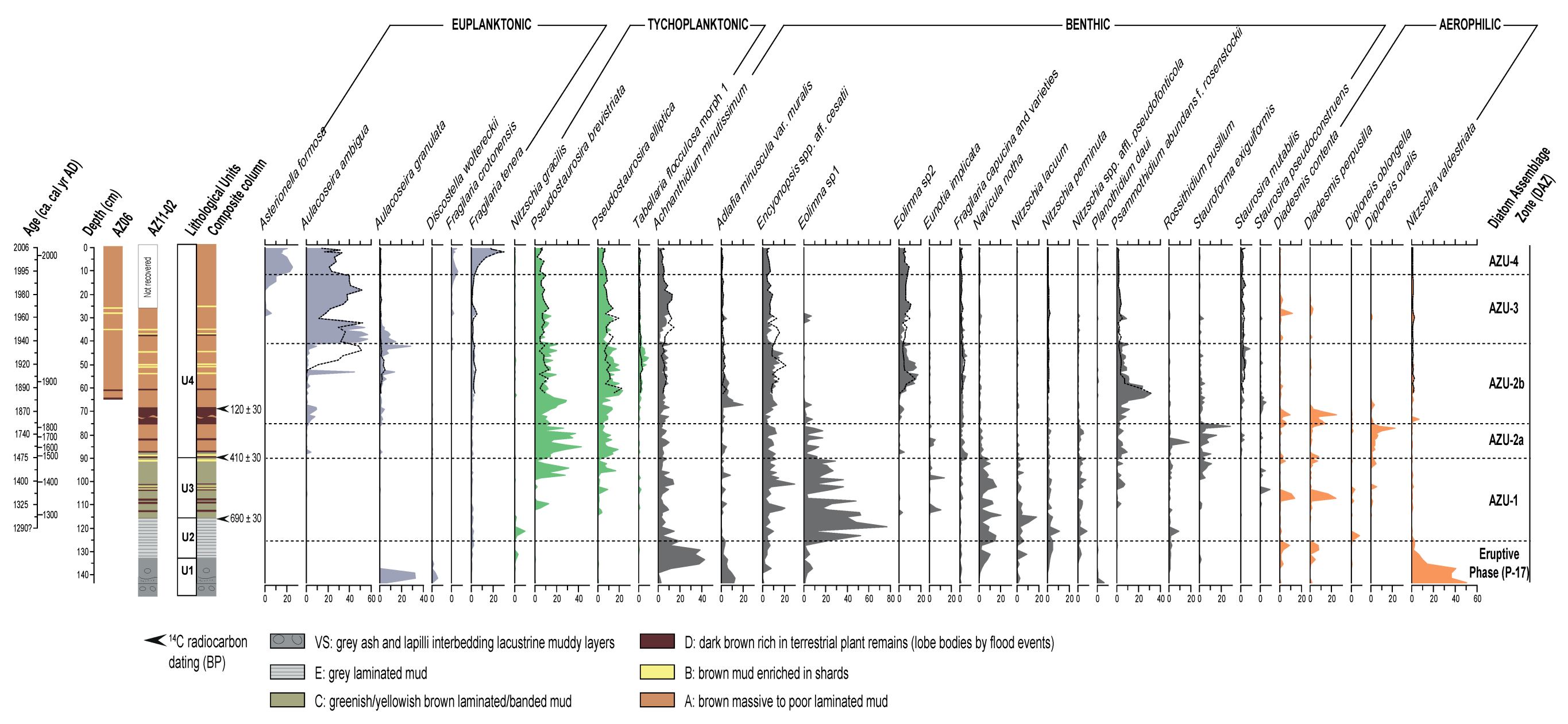

Figure 4 


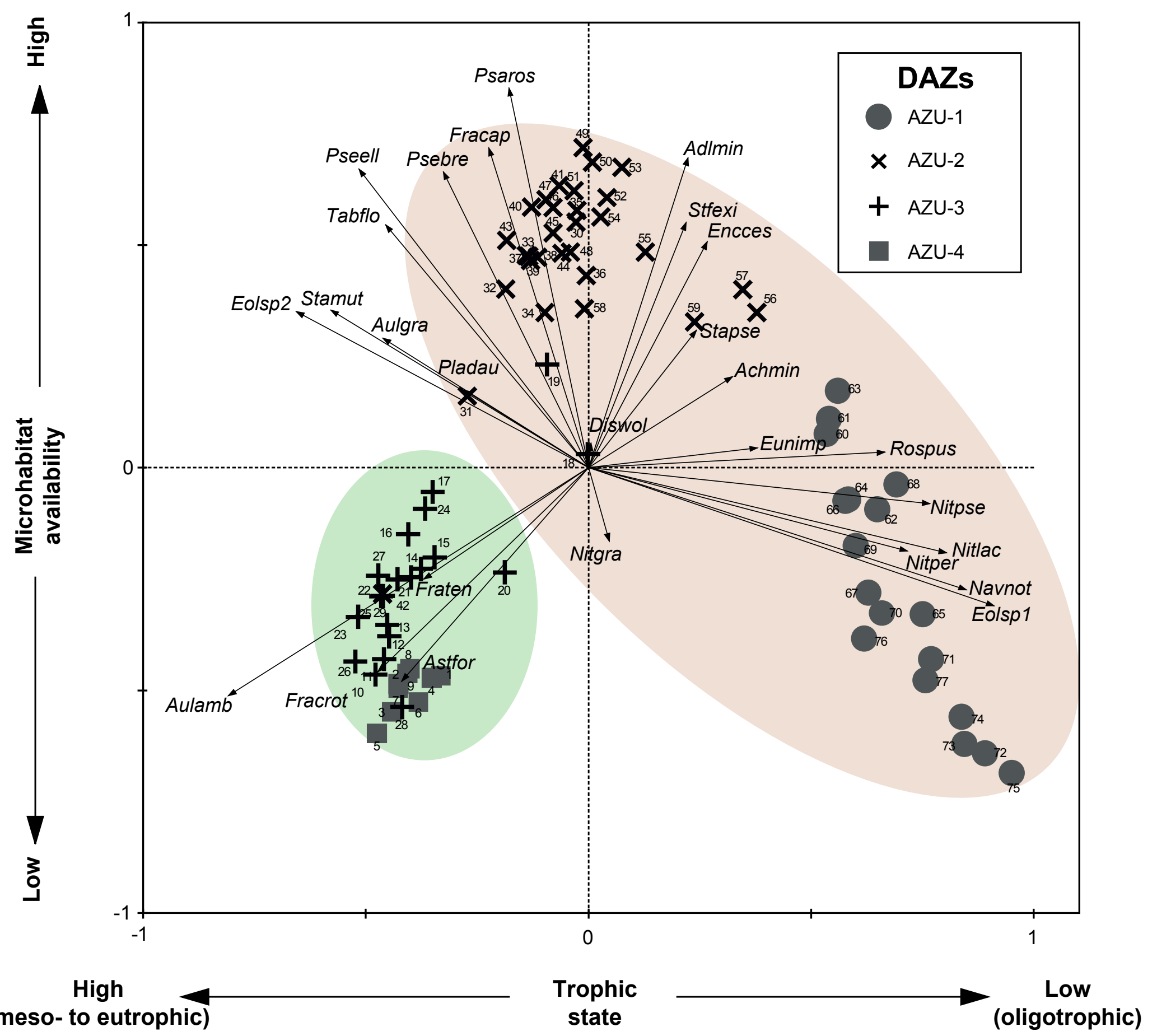

\section{Figure 5}




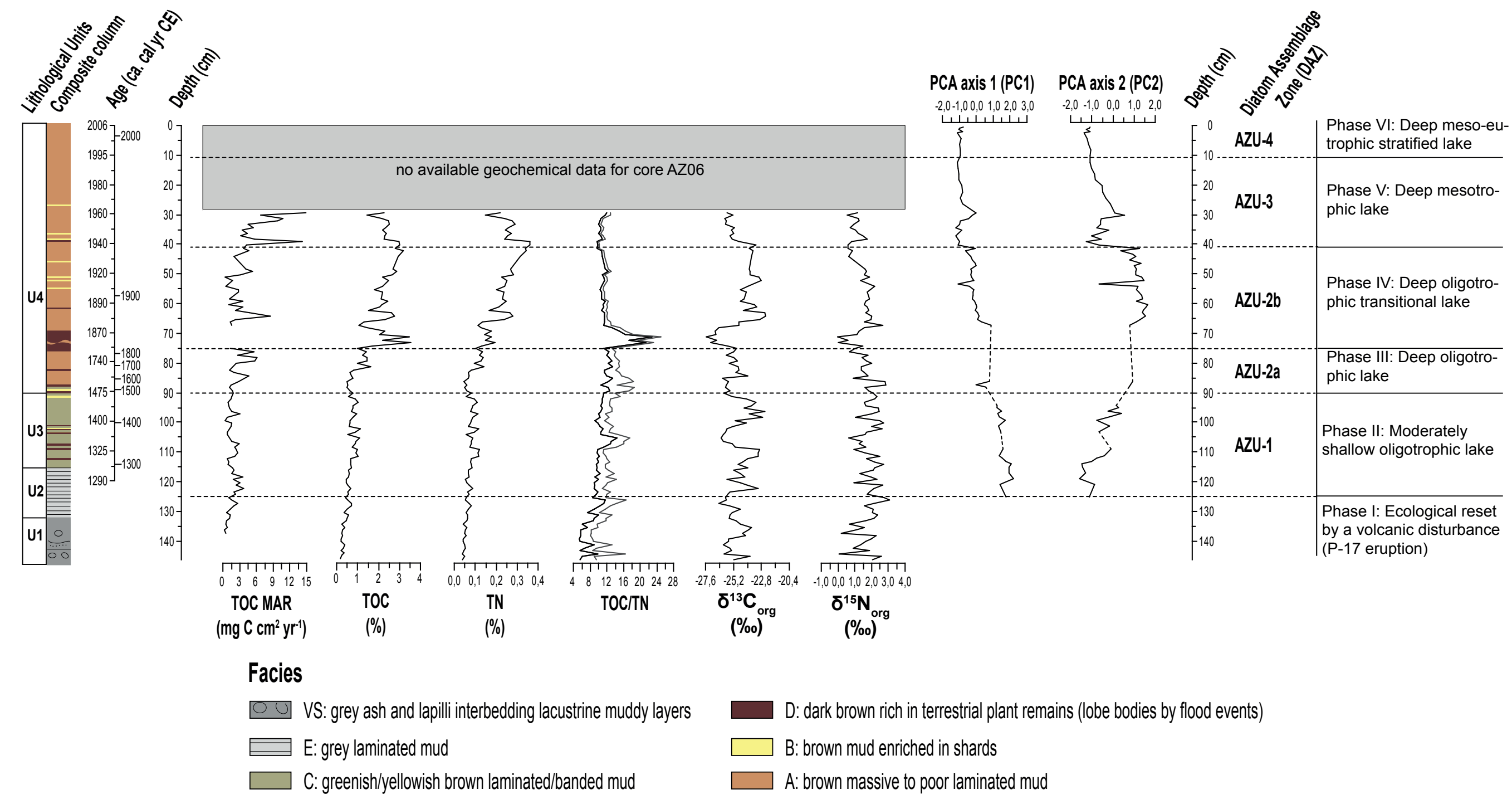

Figure 6 


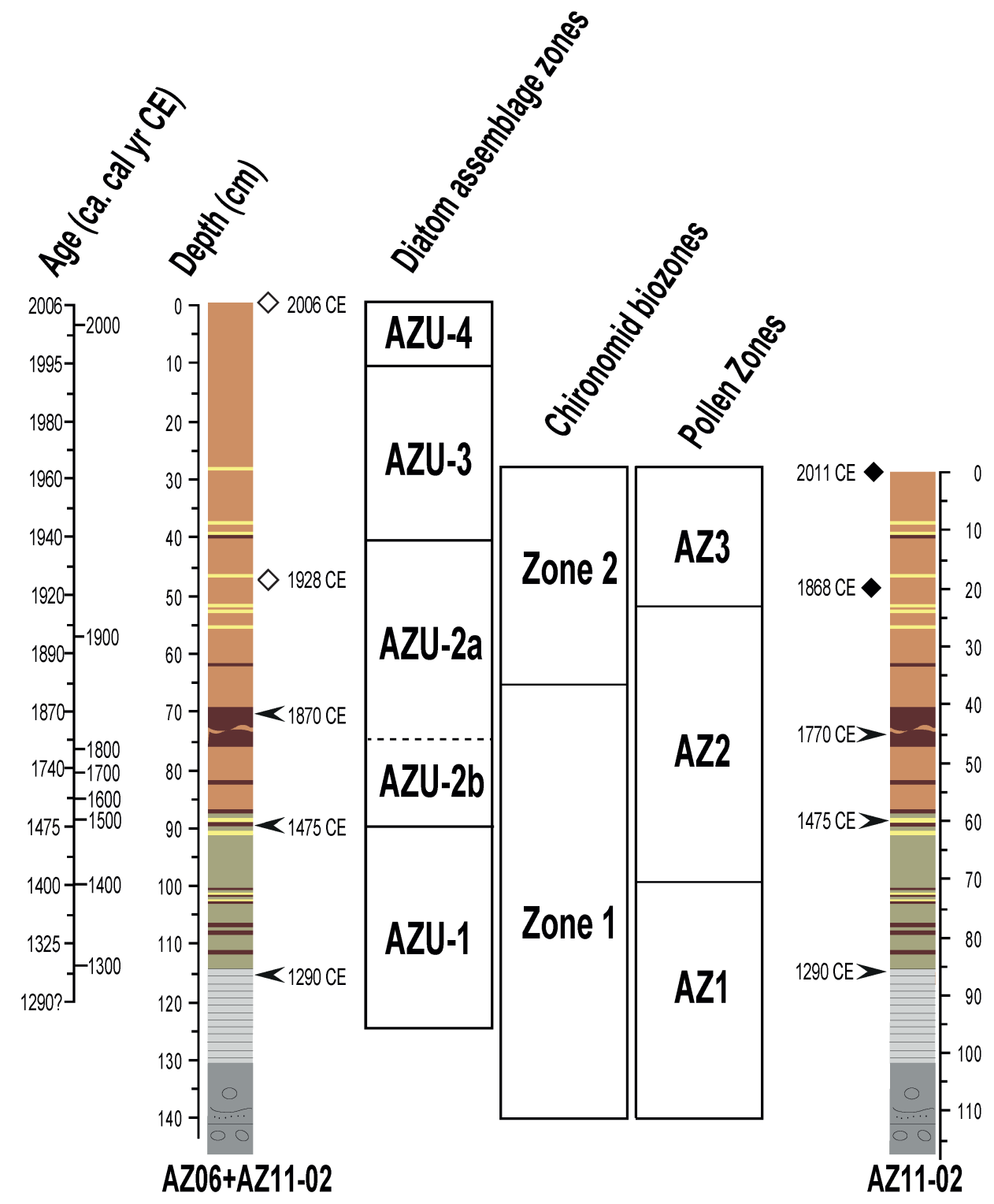

$\diamond \mathrm{Pb}^{210} \mathrm{CF}: \mathrm{CS}$ model for AZ06 (Gonçalves, 2008) and composite column (this study)

- Pb210 CF:CS model for AZ11-02 (Raposeiro et al., 2017; Rull et al., 2017)

$<{ }^{14} \mathrm{C}$ (cal. yr CE)

Facies

$\bigcirc \cup$ VS: grey ash and lapilli interbedding lacustrine muddy layers

$\square$ D: dark brown rich in terrestrial plant remains (lobe bodies by flood events)

E: grey laminated mud

$\square$ B: brown mud enriched in shards

C: greenish/yellowish brown laminated/banded mud

$\square$ A: brown massive to poor laminated mud

\section{Supplementary Material III}

